\title{
التاريخ الثقافي لاولة الامارات العربية المتحدة
}

\author{
$(r \cdot \varepsilon-19 \vee 1)$ \\ أ . م • الدكتور مفيد الزيدي \\ جامعة بغداد / مركز الار اسات الاستر اتيجية و الاولية \\ ملخص البحث
}

تشكل دراسة الثقافة في المجتمع اهمية خاصة لفهم اعمق بطبيعة القوى الاجتماعية و البنى الاقتصادية والتركيبة السكانية لهذا المجتمع لكي تكتمل الصورة لمر احل النمو في تكوينه التاريخي. ويأتي هذا البحث لدراسة (التحولات التقافية في دولة الامارات العربية المتحدة

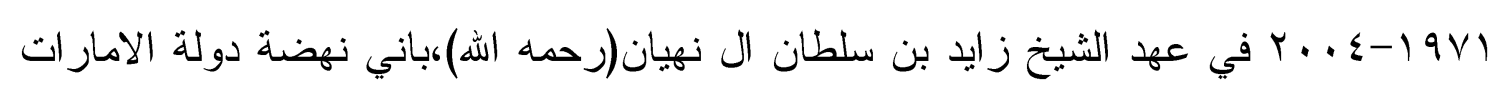
العربية المتحدة في تلك العقود من الزمن. وقد اكتسبت الدولة على غرار بقية دول الخليج

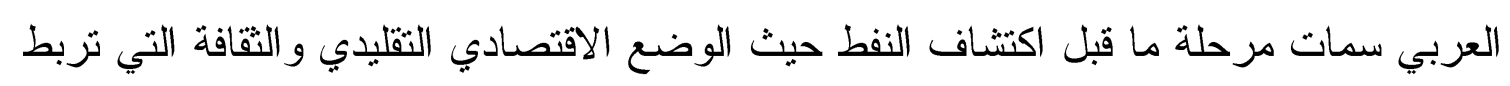

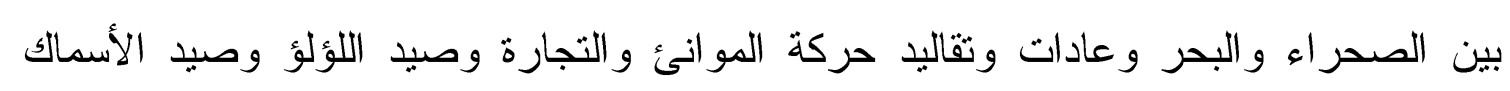

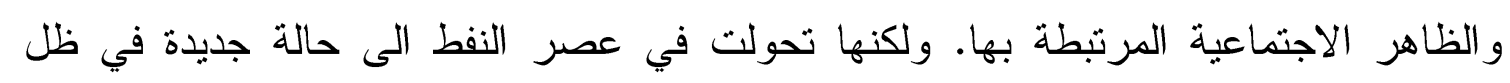

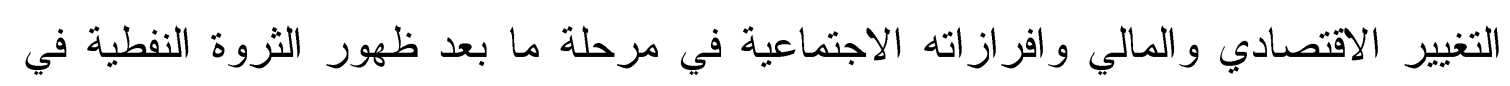
الدولة.

قام الباحث بزيارتين الى دولة الامارات العربية المتحدة، الاولى في عام r ا ب و والثانية في العام الذي تلاها ليطلع ميدانيا وعلميا على طبيعة التحولات من خلال المؤسسات التقافية

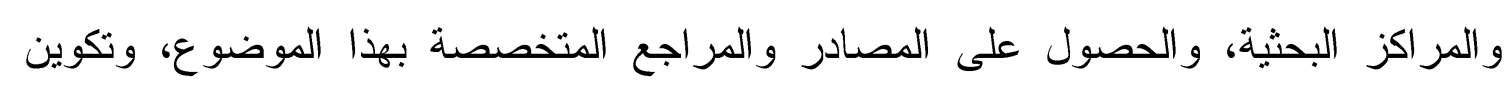
رؤية و اقعية لما وصلت اليه الدولة من تحولات في المجالات الثقافية. ان الفرضية التي نطرحها في هذا البحث بان التغييرات الاقتصادية و الاجتماعية تؤدي لوني

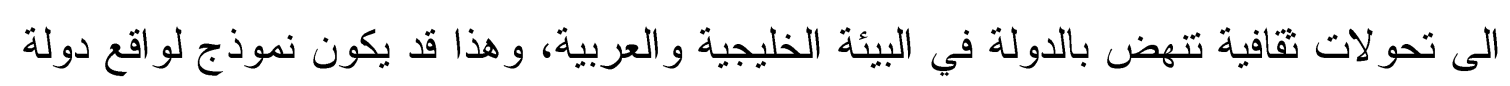

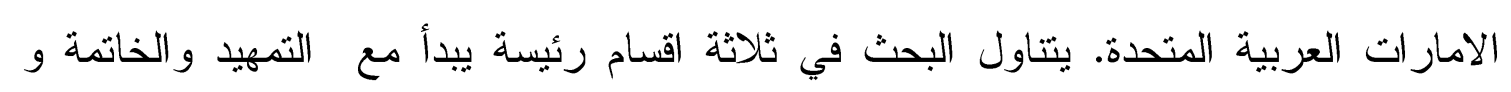


الهو امش وقائمة المر اجع. اذ تحدثا في المبحث الاول عن الاوضاع الاقتصادية لدولة الامارات العربية المتحدة قبل اكتشاف النفط وبعده ،ثم المبحث الثاني عن البنية الاجتماعية للاولة من خلال الفئات الاجتماعية والقبيلة، ثم نمو السكان بعد اكتشاف النفط وتطور المجتمع واشكالية الهجرة الاجنبية. اما المبحث الثالث، فان الحديث ازداد عمقا في اطار التحولات الثقافية في دولة الامار ات العربية المتحدة في مجالات التعليم الحديث، و المنتديات التقافية والجوائز العلمية، و الصحافة والاعلام، و المرأة واسهاماتها العمل الثقافي، والتراث الثقافي الثعبي، ثم الفن التشكيلي والحركة المسرحية ،واخيرا الادب والحركة الادبية وتطور ها خلال تللك الفترة في مختلف المجالات في دولة الامارات العربية المتحدة. وقد اعتمد البحث على عدد كبير من المر اجع الامار اتية العلمية والاكاديمية فضلا عن المراجع العربية والمترجمة و الاجنبية من كتب وبحوث ونشر ات رسمية وتقارير ومو اقع الكترونية متخصصة.

تمهيك :

تشكل دراسة الثقافة في المجتمع اهمية خاصة لفه اعمق بطبيعة القوى الاجتماعية و التركيبة السكانية و البنى الاقتصادية لهذا المجتمع لكي تكتمل الصورة لمراحل النمو في تكوينه التاريخي. فلا يمكن انعز ال الثقافة عن حركة المجتمع والتغيرات التي يمر بها لكون الثقافة هي نتاج تللك التغيرات اساسا، والتي تعبر عن ارادة الانسان وادراكه لحركة العصر ومتطلباته و بالتالي يبدا بالتفاعل معها.ويأتي هذا البحث لدراسة التاريخ التقافي لدولة الامارات العربية

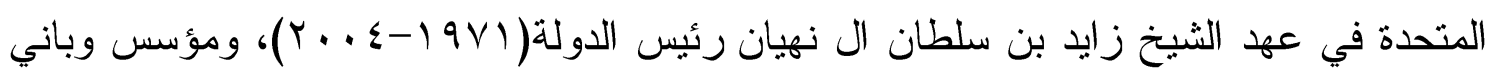
نهضة دولة الامارات العربية المتحدة. وقد اكتسبت الدولة على غرار بقية دول الخليج العربي سمات مرحلة ما قبل اكتشاف النفط حيث الوضع الاقتصادي التقليدي والثقافة التي ثربط بين الصحر اء و البحر وعادات وتقاليد حركة الموانئ والتجارة وصيد اللؤلؤ وصيد الأسماك ورياضة صيد الحيوانات البرية والظاهر الاجتماعية المرتبطة بها. ولكن الدولة تحولت في بعد اكتشاف النفط الى حالة جديدة في ظل التغيير الاقتصادي و المالي و افراز اته الاجتماعية بعد ظهور الثروة النفطية.وقام الباحث بزيارتين الى دولة الامار ات العربية المتحدة الاولى في عام r ا ـ ب و الثانية في عام با ـ ب ليطلع على طبيعة التحولات التقافية بالتو اصل مع المؤسسات التقافية و المر اكز 
البحثية، و الحصول على المصادر و المر اجع المتخصصة بهذا الموضوع، وتكوين رؤية ميدانية لما وصلت اليه الدولة في المجال الثقافي. و الفرضية التي نطرحها في هذا البحث بان التغييرات الاقتصادية والاجتماعية تؤدي الى التحولات الثقافية وتأسيس خطاب ثقافي تتهض بالمجتمع و الدولة في البيئة الخليجية و العربية و هذا قد يكون نموذجا لو اقع دولة الامار ات العربية المتحدة. ومن الناحية الجغر افية، تقع دولة الأمار ات العربية المتحدة في جنوب شرق شبه الجزيرة العربية وتمتد من خليج عمان شرقا حتى قطر غربا ويحدها من الشمال و الشمال الغربي الخليج العربي

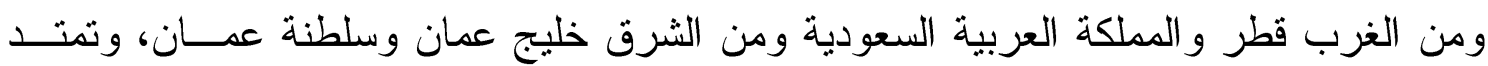
سو احل دولة الامارات المطلة على الساحل الجنوبي للخليج العربي مسافة ؟ ؟ اكـــم مــن شــبه جزيرة قطر غربا وحتى راس مسندم شرقا علما ان ابو ظبي تشكل الجـزء الاكبــر بمســاحة

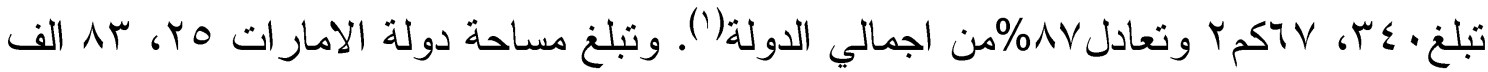

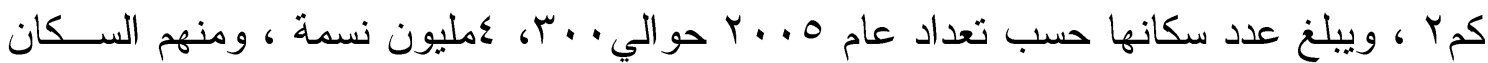

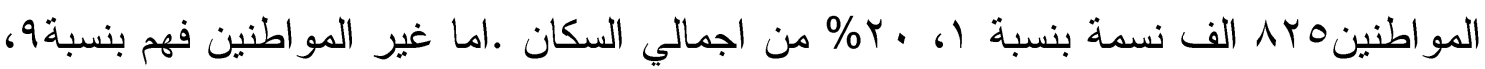
\% اي حو الي • AV لقد حققت دولة الامار ات العربية المتحدة استقلالها وتكوين دولة الاتحاد في الثاني مسـن كـانون الاول/ديسمبر الو اكدولة مستقلة، ثم العمل بالدستور المؤقت و انتخاب الشيخ زايد بن سلطان ال نهيان حاكم امارة ابو ظبي رئيسا للاولة وتألف الاتحاد من ست امار ات انضــمت بعـدها رأس الخيمة له في • اشباط/فبر اير 9 IV ، و اصبحت الدولة عضو في جامعة الدول العربية ومنظمة

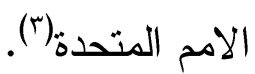
وكان الشيخ زايد بن سلطان ال نهيان رئيس الدولة ومؤسس الاتحاد وداعم فكرته، فهو الــزعيم و الاب المؤسس لدولة الامار ات العربية المتحدة، وضـع اسس عهد جديد لبناء انســان ومرحلــة جديدة في التاريخ السياسي للدولة فرسخ رؤية نهضوية وحدوية تتويرية تلامس الواقع العملــي، و أخذ الدولة دن حالة التجزئة الى الوحدة، ومن الانغلاق الى الانفتاح ومن القبيلة الى الدولة ومن التقليد الى الحياة الحديثة المو اكبة للعصر • و أصبحت دولة الامار ات خلال سنوات حكمه نموذجا يحتذى به خليجيا و اقليميا ودوليا بعد ان اشرف الشيخ زايد على خطوات الاتحـــاد و الاســتقلال 
و التحول من التأسيس الى البناء، وتكمن اهمية نظرثه في الاستثمار لبس المادي بل الاســتثمار

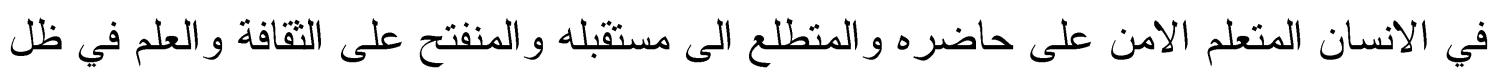
دولة منطورة اقتصاديا وثقافيا وعلميا وتكنولوجيا بحيث وصلت دولة الامار ات العربية المتحدة

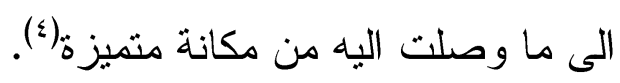

\section{أولا : الأوضطاع الاقتصاصية.}

شهد مجتمع الخليج العربي قبل اكتثاف النفط ظروف اقتصادية صعبة نظرا لقلة الموارد المعيشية واعتماده على البحر كمورد للرزق عن طريق الغوص على اللؤلؤ او صيد الاسماك و التجارة المحدودة مع الدول المجاورة لها، فضلا عن صناعة السفن وشباك الصيد. وكانت حرفة الغوص على اللؤلؤ المصدر الرئيس للرزق وكسب العيش لاسيما المناطق الساحلية، ومن ثم التجارة مع الهند وايران وشرق افريقيا والتي اكتسب منها المجتمع الخليجي عادات وتقاليد وثقافات ولغات وفنون وازياء وآداب نقلها التجار العرب او التجار الاخرين القادمين للمنطقة ايضا(ه).وقد عمل الناس الى جانب الغوص في حرفة الزراعة واعة والرعي في البادية ،وظهرت ايضا صناعات بسيطة مثل تجفيف الملح وصناعة السلال وكبس التمور وعمل الفخار وشباك الصيد و ادوات الزر اعة والاخشاب و المسامير و الحبال و التي تخص العمل في الزر اعة وصناعة السفن و القوارب الصغيرة. الا ان اكتشاف النفط ادى الى تدفق العو ائد المالية على دول الخليج العربي،وتحول النفط في امارات ساحل عمان الى عامل مهم في التغيير الاقتصادي والاجتماعي و الدخل القومي بنسبةه-م، 9\% منه ،ووصل الى ثلاثة ملايين دولار عام • •197 في امارات ساحل عمان، وارتفع الى بrr مليون دولار عام • 19V1 ثم الى . .اء مليون دولار عام (?) $19 \vee \varepsilon$

و ادى الوضع الجديد في التغيير الاقتصادي الى تحول في الحياة التقافية مـن القـيم والعــادات وظهور ثقافات جديدة وحركة تحديث مع التحول من مجتمع بسيط الى مجتمع جديد تطغي عليه الثروة المالية بالاعتماد على الريع النفطي ، وظهور سمات اجتماعية وتحو لات ثقافية تبعا لتلاك

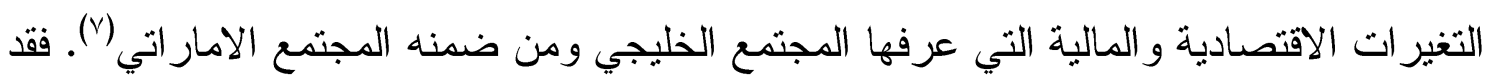
شهدت دولة الامار ات العربية المتحدة ولاز الت نموا متصـاعدا في المجــال الاقتصــادي علـى 
المستوى الخليجي و العربي و العالمي وازدياد الاحتياطي النفطي فيها ليبلغ عام ، 199 حو الي )

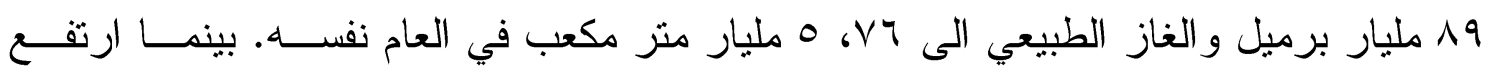

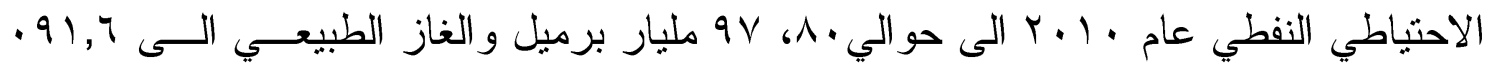

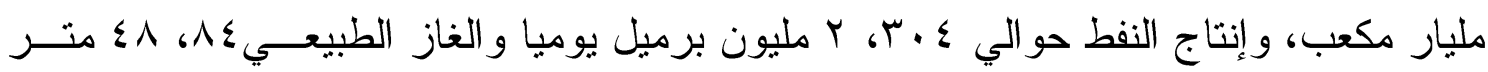

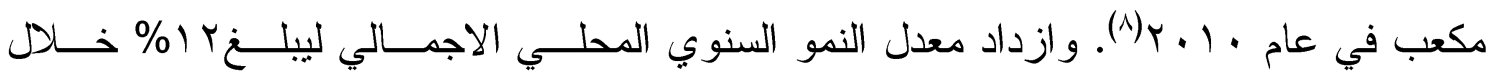

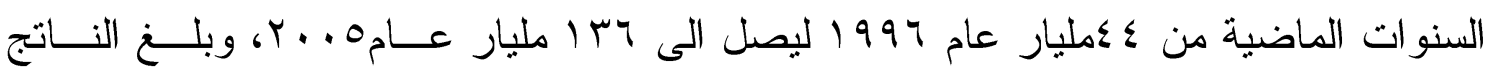

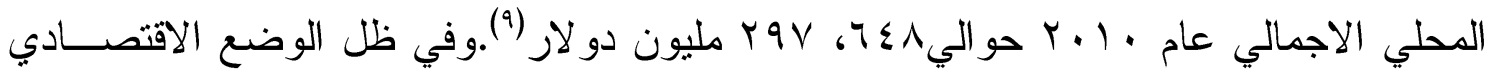
الجديد لدولة الامار ات العربية المتحدة، تبرز امارة دبي اكبر و اغنى المدن انتعاشـــا اقتصـــاديا وتجاريا وماليا و استثماريا، وتقف في مقدمة دول الخليج العربي و الدول العربية كافــة الاكثــر انفتاحا على العالم الخارجي ودخلت في قائمة المدن الاكثر نموا في العالم، وتحولت الى مدينــة تجارية ومركز سياحي ومالي اقليمي، ومحطة اقتصادية على المستوى الاقليمي و العــالمي بمــا

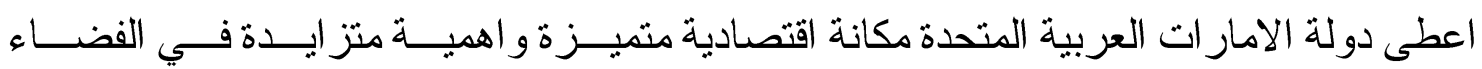
الاقتصادي العالمي (·) (1). ثانيا: البنية الاجتماعية: تمنل القيلة مرحلة في الحياة السياسية والاقتصادية والاجتماعية في منطقة الخليج العربي ومنها دولة الامار ات العربية المتحدة قبل اكتشاف النفط وهيمنة القبيلــة علـى الحيــاة الاجتماعيــة و الاقتصادية ، وكانت البيئة قاسية ليس فيها تعليم على نطاق و اسع، و الامية منتشــرة و الثقافــة بسيطة مرثبطة باقتصاد الكفاف، وظهرث فئات اجتماعية من الاسر الحاكمة وصــغار التجــار وز عماء القبائل و اصحاب الاملاك و المز ارعين و البدو ('). وارتكز التنظيم السياسي والاجتماعي و الثقافي في المجتمع الامار اتي بشان وحدة القبيلة و انتشرت القبائل في مختلف المناطق ومنهــا في ابو ظبي( بنوياس و المناصير و العو امر)، ودبي(ال بوفلاسة و السودان و المرر)، و الثــارقة (القو اسم و المزاريع و ال بنونعيم وال علي و الثـــــ امس و الطنــيح)، ور اس الخيمــة (القواســـ

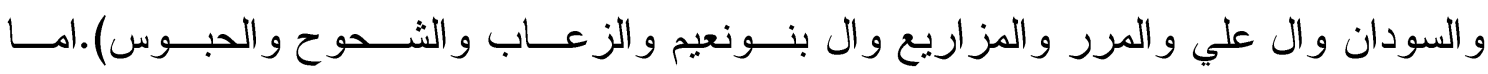
عجمان(ال بنونعيم و السودان وال بوههير)، وام القيوين(ال علي) و الفجيرة(الشرقيون)، و عاشت 
مع هذه القبائل العربية الاصيلة مجموعات سكانية اخرى قادمة من شبه القارة الهندية وايـران

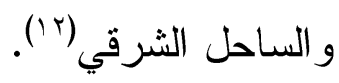

وبعد اكتثاف النفط تغيرت البنية الاجنماعية وحلت قوى وفئات جديدة الى جانب الاسر الحاكمة و العلماء والاسر التجارية الكبيرة والطبقة الوسطى والعمال، وبرزت رؤى ثقافية جديدة في هذا

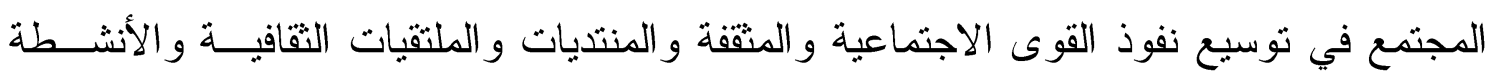

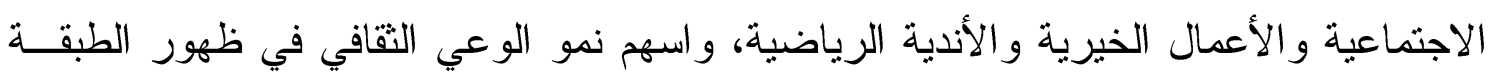
الوسطى على الصعيد الاجتماعي التي أسهوت في إقامة الجمعيات و الاندية الثقافية والصــحافة

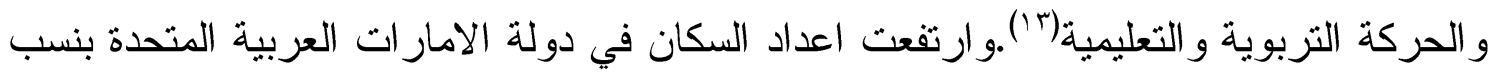

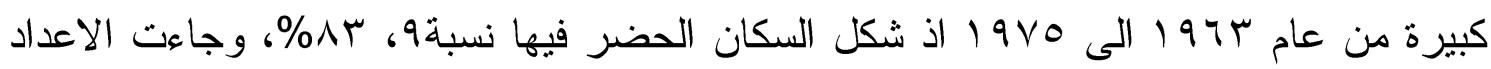

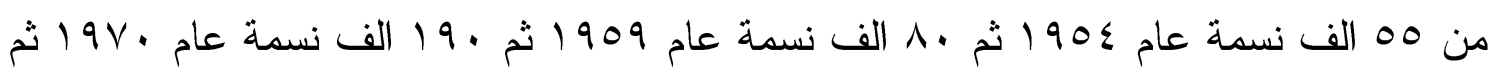

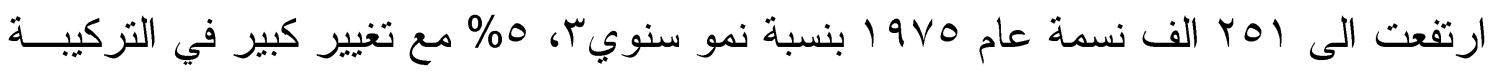

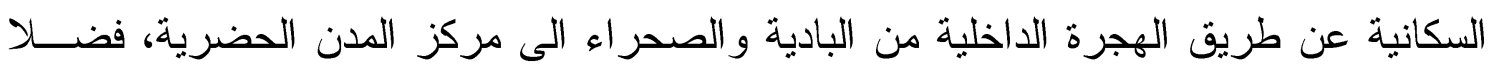

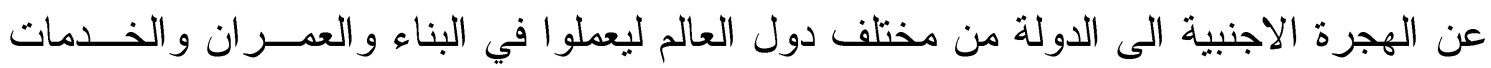

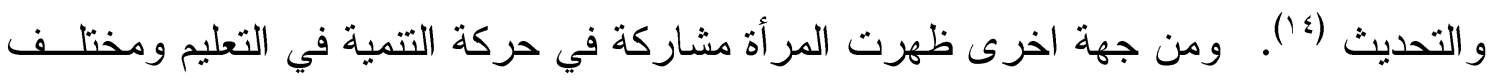
مجالات العمل و الوظائف في الطب و الصيدلة و التدريس و الهندسة و الادب و الفنـــون وغيرهـــا، وساهمت في الحياة في محاولة للحصول على حقوقها السياسية و الاجتماعية بحيــث انـدمجت المرأة بمرور الزمن في المجتمع الجديد الى حد كبير.

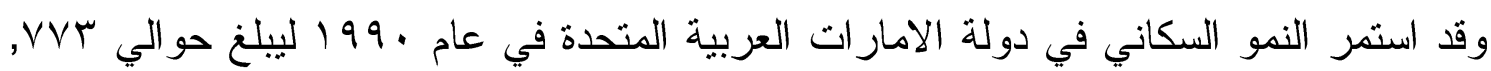

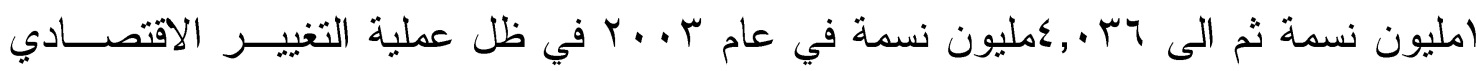
و الاجتماعي التي شهدتها الدولة، ومنها الهجرة الداخلية نحو الددن و الحواضر، وهجرة اجنبيــة كبيرة الى الدولة وخاصة من الجاليات الاسيوية، وهذا الواقع الاجتماعي الجديد افــرز تقافـات و افكار جديدة تمثلت في الاندية و الجمعيات التقافية و الاجتماعية و الصـــافة وحركسـة الطباعــة

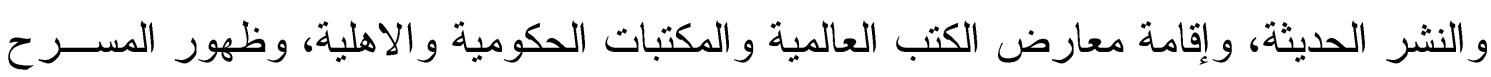


و الفنون التشكيلية و الحركة الادبية و الفنية، ودخول التكنولوجية الحديثة الى ميادين التعليم العـام

و التعليم العالي ومختلف مجالات العمل في الدولة (10). من جهة اخرى، فان ظاهرة الهجرة الاجنبية من الناحية الاجتماعية القت بظلالها على المجتمع الخليجي عامة، اذ يرى بعض الاجتماعيين و المثقفين ان الهجرة افرزت ارهاصات جديدة فـي انتشار اللغات و اللهجات الاجنبية وفي مقدمتها الاسيوية داخل المجتمع، والمصطلحات الاوربية و الاسيوية في المخاطبات اليومية، ويشكل هذا بالتالي تهديدا للثقافة المحلية نتيجة سيادة التقافات الو افدة بين السكان المحليين ،و الخشية الى حد ما من تهديدها للتقاليد و الاعر اف و القيم و العادات

$$
\text { و الموروثات الشعبية(1) (1). }
$$

\section{ثالثا: بنية التحولات الثقافية فيـ صرولة الامارات .}

امتزجت الحياة الاجنماعية بالواقع الثقافي في امارات ساحل عمان، لان ثقافة الانسان تحدد نوع وطبيعة الحياة التي يعيشها، مثل البيئة الساحلية التي ارتبطت بثقافة الساحل مقارنة بييئة الداخل او الصحر اء، ومن ثم حددث الهوية الثقافية للإنسان و المجتمع في الدولة التي نشأت فيما بعد وهي دولة الامارات العربية المتحدة، والتي تتمثل بالهوية الوطنية و العربية الاسلامية، وتحولت الحياة الثقافية في الدولة اسوة بيقية دول الخليج العربي من نمط حياة بسيطة الى حياة حديثة، وانفتح المجتمع على التقافات والافكار و التجارب العربية و العالمية، فرضت وجودها على الانسان الخليجي لتحل محل الثقافة القبلية بشكل تدريجي وانتشر التحليم الحديث بين الثباب المتعمين و المتتورين وأرسال البعثات الدراسية الى الدول العربية والاجنبية، ودراسة العلوم و المعارف الحديثة ومجيء الخبراء و المدرسين و الفنبين العرب والاجانب لنقل تجاربهم وخبر اتهم في شتى العلوم الانسانية و العلمية(V). ونشات نتيجة ذلك نخب متعلمة ومثقفة اسهمت في التحولات الثقافية بعد ان امتلكـــ الخبـرات و المؤهلات العلمية و اطلعت على الخبرات العربية و الغربية المتقدمة وعملت بعد عودتهــا الـىى الدولة على تعزيز العمل الثقافي و العلمي في مختلف مجالاته، وسمح ذلك بالانفتاح على الثقافات الجديدة وتتوع الثقافة المحلية و الانفتاح على الهوية الوطنية وظهور قيم جديدة في الحداثة ونبــذ المفاهيم القديمة، وظهرت قيم و اتجاهات اكثر و عيا تجاه الوطن و المواطنة وتعددت أوجه الثقافة 
مع تطور الطباعة والصحافة و الاعلام، وصدور الصـــف اليوميــة والمجــلات الاســبوعية و الثهرية ونشوء فئة من الكتاب و الباحثين الموطنين كجيل من الثباب المتعلمين ودخول المطابع الحديثة المحلية بديلا الى حد كبير عن الطباعة في العو اصم العربية كالقاهرة وبيروت ودمشق، وظهرت صحف ومجلات كالاتحاد و الخليج واخبار الخليج وزهرة الخليج و البيان وغيرها لقيت

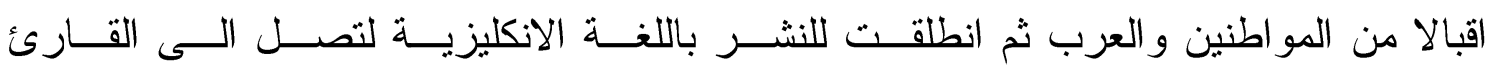
الاجنبي(1).وقد تحققت انجاز ات كبيرة في ظل حكمة ورعاية الشيخ زايد بن سلطان ال نهيــان في الجانب الثقافي والابداعي واحياء التراث الثعبي و الثشعر وخاصة الثُعر النبطي، والقصــة القصيرة و الحكاية الثعبية و المسرح و الفن التشكيلي و الاعلام و الصــــافة و الغنـــاء و المؤلفــات

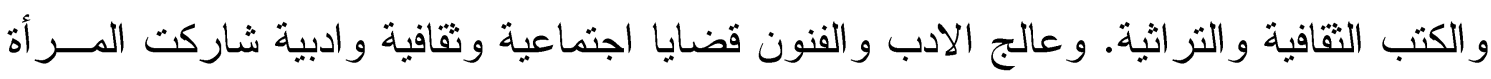
في نصيب منها، وحفل النتاج الادبي بالاعتماد على التزاث و الثقاليد الوطنية والموروث الشعبي الى جانب الاستفادة من الترجمات العالمية والتجارب الاجنبية، وبذلك عبرت المرحلة الجديـدة عن تغير ات اجتماعية وثقافية شهـتها دولة الامار ات العربية المتحدة منــذ ســبعينيات القـرن

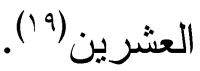

\section{I النعليم العصيث}

كان التعليم في امارات ساحل عمان تعليما تقليديا للمطاوعة والكتاتيب مثل بقية دول المنطقة ويسمى المطاوعة احيانا الملا او الثيخ او الفقيه، إلى ان ظهر التعليم في بدايات القرن العشرين نتيجة تجارة اللؤلؤ، وارتباط المنطقة بالحركة الثقافية في مصر وبلاد الثام والملاحة بين دبي وبومباي و الخط الصحر اوي بين دمشق-بغداد عام ع 19 ا عبر امارات ساحل عمان، وبدء مجيء المعلمين و المفكرين العرب الى دول الخليج العربي، ونشأ التعليم على ايدي التجار و اقتصر على الذكور فحسب. ثم اعتمدث المدارس الاولى على المناهج الدراسية والمعلمين من مصر وسوريا و العر اق ، وكانت مدارس شبه نظامية في ذلك الوقت، ومن ابرزها في الثارقة المدرسة القيمية المحمودية عامV•919، و المدرسة الوهبية عام ال19 (6و المدرسة النابودية عام

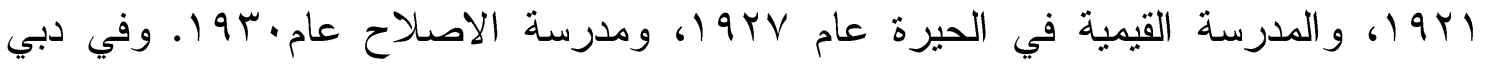

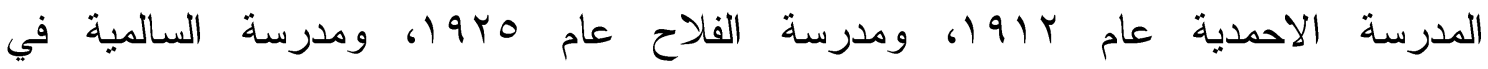


الديرةعامس 9 (.وفي ابوظبي مدرسة ابن عتيبة عام. ب9 ا، ومدرسة درويش بن كرم عام • ـ9 .وفي راس الخيمة المدرسة القاسمية ومدرسة المعيريض عامعاو (، ومدرسة الفتح

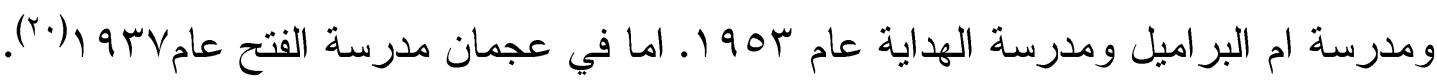
ثم دخل التعليم (النظامي) في دولة الامار ات العربية بمساعدة عربية منذ نهاية الحرب العالميــة الثانية مع اكتشاف النفط في البلاد الذي انعكس على الحركة التعليمية وتطور ها. ففي عام سه 190 كانت بداية التعليم الحديث في المدرسة القاسمية بالشارقة، و عام 1900 المدرسة الاحمدية فـي

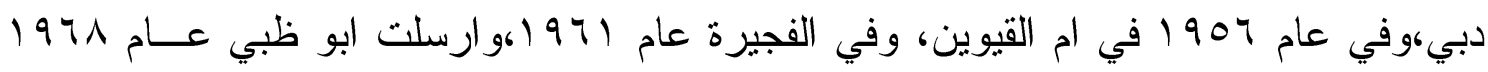
المدرسين الى مدارس امار ات الشمال وبلغ عددهم V؛ مدرسا ووصل الى . . 1 مدرسا عــام

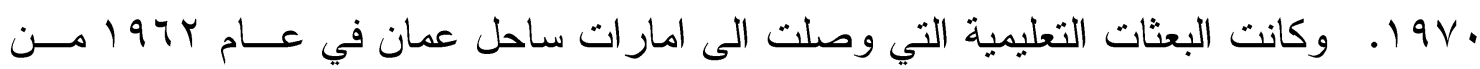

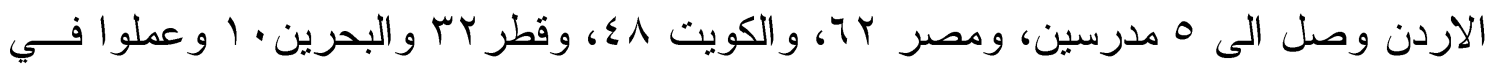
مدارس الامار ات آنذاك('r).وكان تطور التعليم في ابو ظبي مرتبط اساسا بالشيخ زايد بن سلطان ال نهيان الذي جعل التعليم موضع اهتمامه الاول منذ توليه الحكم مــن خــلال زيــادة اعـــداد المدارس و المدرسين و المعلمين و المناهج الدر اسية الحديثة بحيث وصل اعــداد الطــلاب فـي

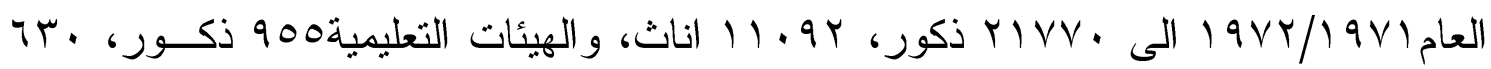
اناث. اما عدد المدارس فكانت بـ للبنين و اب للبنات لتصبح مجموعهاس Vدرسة(rr). وساعدت السلطات البريطانية في دعم التعليم في امار ات ساحل عمان مثـلـ انثـــاء المدرســة الصناعية في الثارقة عام1901 الدعم التعليم الحرفي، ثم تبعتها المدرسة الصناعية في دبي عام اج79 أن اجل تكوين كو ادر مهنية متخصصة، ثم المدرسة الزر اعية في راس الخيمــة عــام

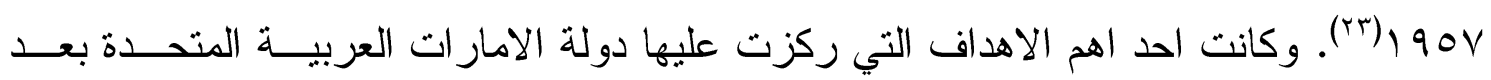
الاتحاد وبدايات تأسيسها هي “نشر التعليم في كل بقعة مسـن ارض الدولــة “، وقامــت وزارة التربية و التعليم التي تر اسها آنذاك عبداله بن عمران تريم بمهام نشر التعليم وتوفيره لكل مواطن وجعله الز اميا في مرحلة الابتدائية ومجانيا في كل مر احله داخل الاتحــاد، ووضـــع الخطــط التعليمية و المناهج الدر اسية ومحو الامية و انشاء المدارس و المعاهد المهنية و العليـــا الجامعيــة و انشاء المدارس الخاصة و ايفاد البعثات الى الخارج(ع)و اكد الشيخ زايد بن سلطان ال نهـــان 
رئيس الدولة منذ البداية ان العلم حق لكل مواطن فوق ارض الدولة، وان الدولة مســئولة عـن تعليم ابنائها وتوفير الظروف المناسبة لهم ونشر التعليم في الدولة، و الاهتمام بالتعليم كما وكيفا،

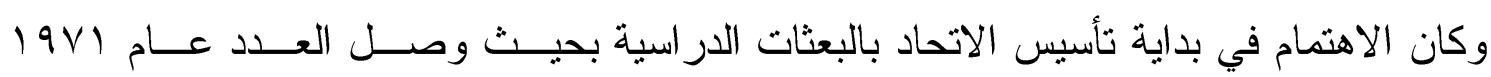
حوالي ـــ من المنح و البعثات الدراسية ليس من ابناء الدولة فحسب بل من دول اخرى منـلـل المملكة العربية السعودية وسلطنة عمان و البحرين وفلسطين و السودان و السنغال وساحل العــاج و إندونيسيا ونيجيريا و غيرها من حصلوا على شهادات الماجستير و الدكتور اه فضلا عن ارســال

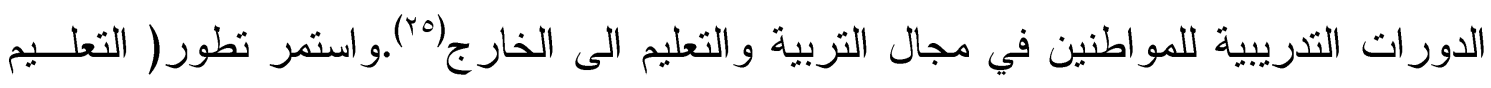
العام) في الدولة الى ان تسلدت وزارة التربية و التعليم الاتحادية لمسؤوليتها في عام بلو ا، وتم

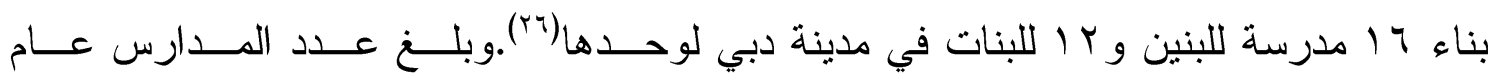

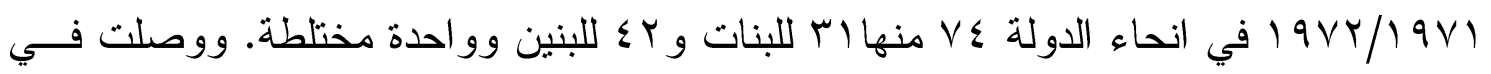

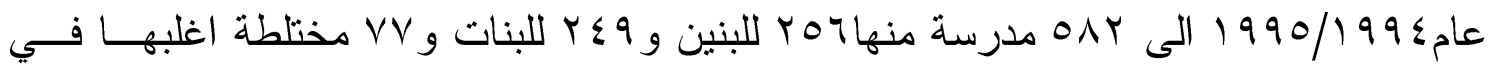

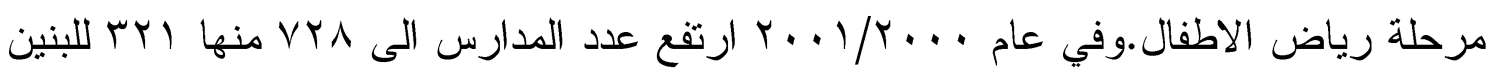

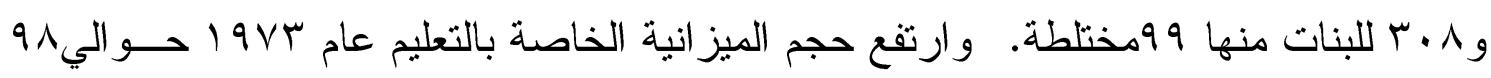

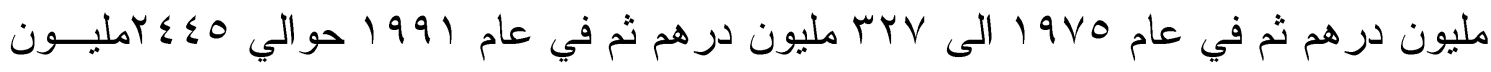

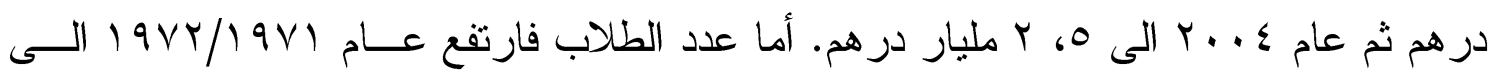

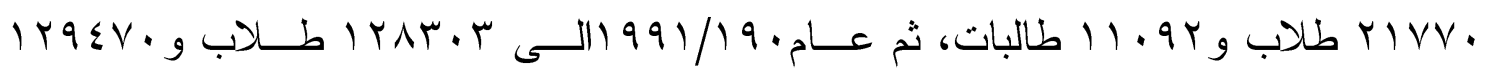

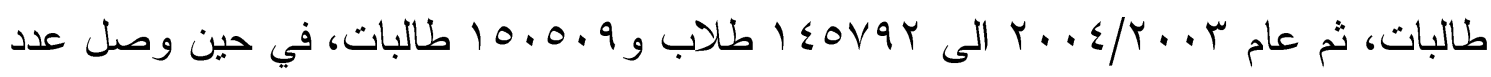

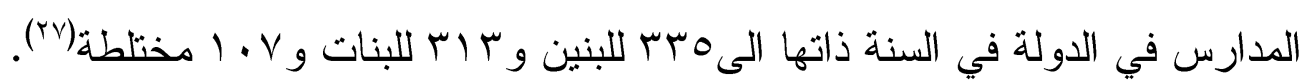
اما( التعليم الخاص)، فقد ادى التغيير الاقتصادي وارتفاع مستوى دخل الفرد وتحسن مســتوى المعيثة الى ازدياد اعداد المدارس الخاصة في دولة الامار ات العربية المتحدة التي وصلت فـي

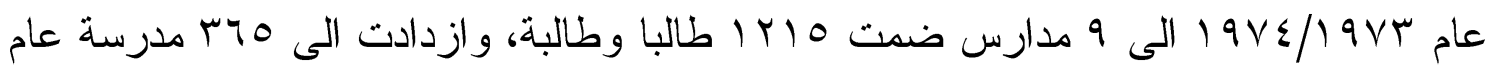

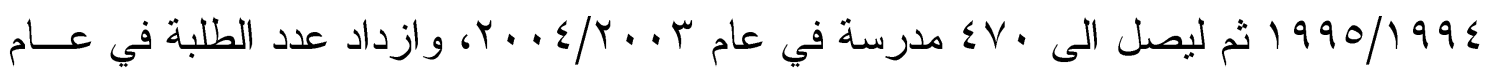

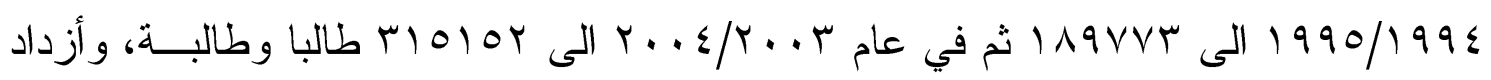

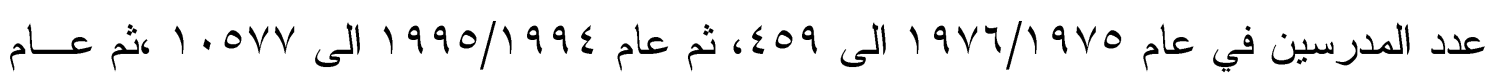




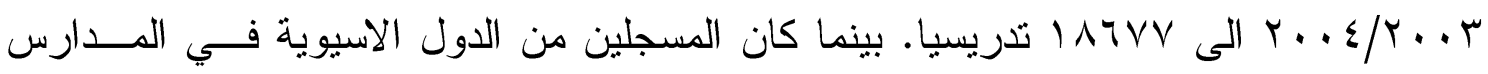

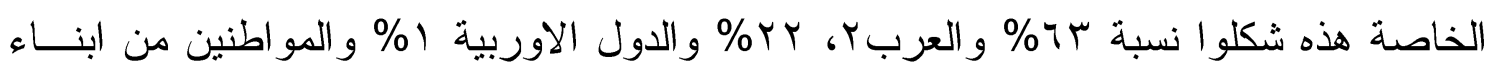

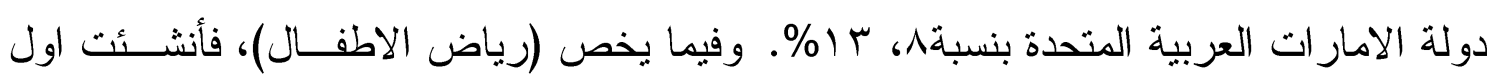

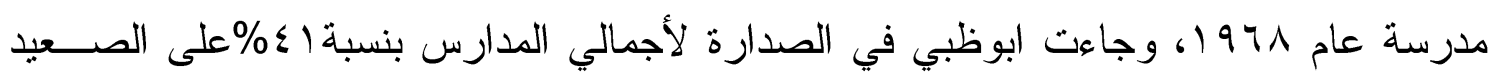

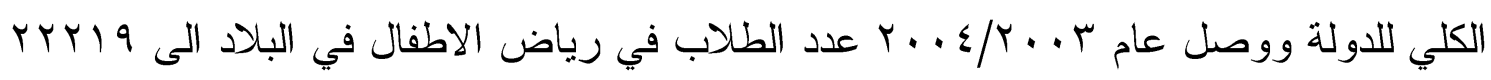
طفل بنسبة9\%من اجمالي الطلاب في جميع المر احل في البلاد. اما (التعليم الفنـي و المهنــي)

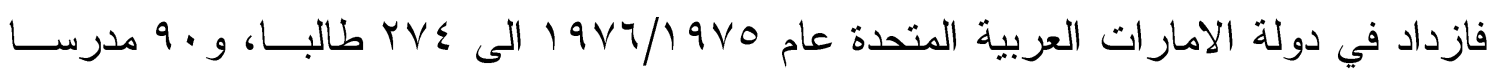

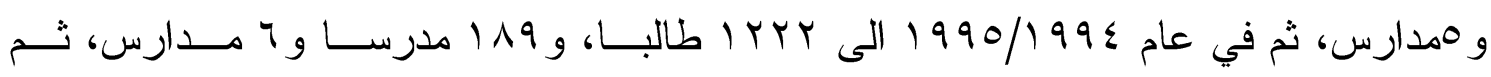

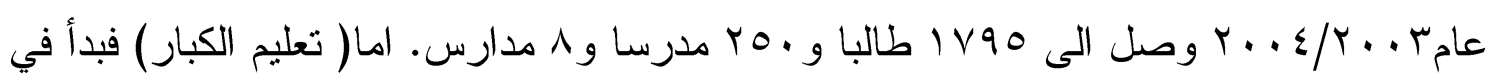
خمسينيات القرن العشرين كأول مركز تعليمي في 900 1907/19 تحت اشر اف البعثة الكويتيـــة ووصل العدد عـام

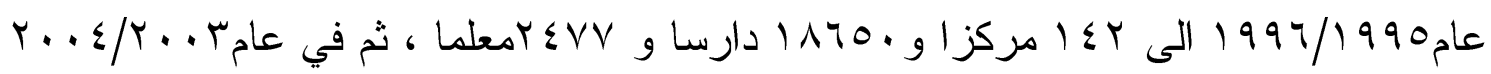

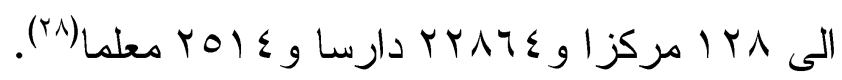
وفي مجال(التعليم العالي)، فقد اصدر الثيخ زايد بن سلطان ال نهيان عام 9 الثرارا

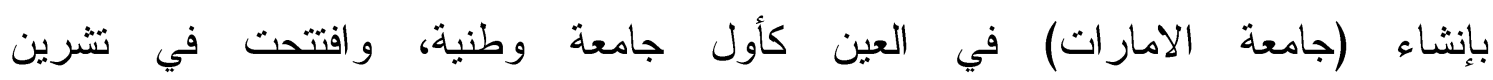
الاول/اكتوبر I YVVV لتوفير التعليم العالي لأبناء الامارات من البنين و البنات. و وعلى الرغم من تأخر ظهور الجامعات في الدولة مقارنة بالكويت و المملكة العربية السعودية. ولكن دولة الامارات العربية المتحدة شهدت قفزة واسعة في عقدي الثمانينيات و التسعينيات من القرن

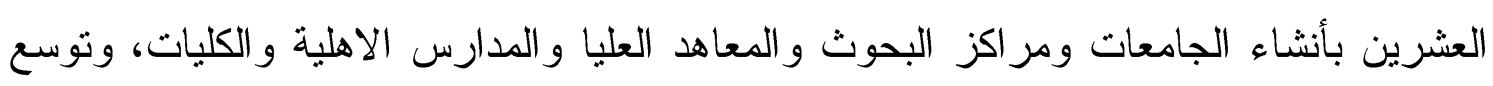
التخصصات الادبية والانسانية و العلمية واستقدام الاساتذة العرب و الاجانب الاكفاء للعمل في هذه

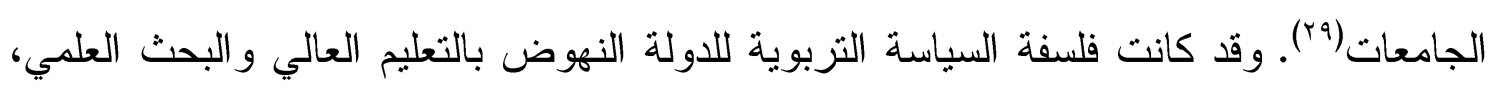

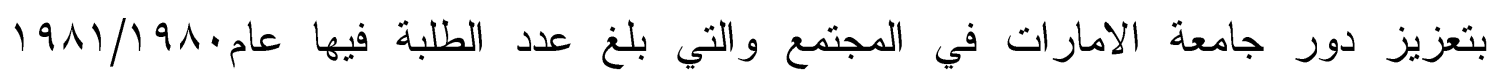
الى • Y ط طالبا، و . . . استاذا لكي تأخذ مكانتها العلمية و البحثية في اوساط الجامعات العربية

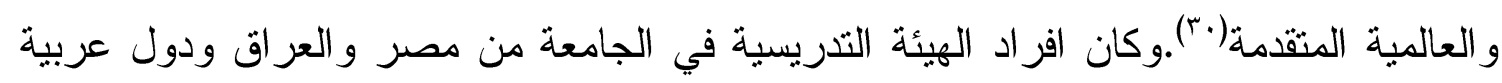


اخرى، وفي تموز/يوليو ب191 اصبح الثيخ نهيان بن مبارك ال نهيان رئيسا للجامعة وتوسعت التخصصات فيها من العلوم الانسانية والتخصصات الهندية والعلمية، وتخرجت اول دفعة من كلية الطب عام ب991، وتأسست اول كلية تقنية عليا عام 9191، وتوسعت الى كليات في ابوظبي و العين ودبي ثم في عام بو 199 الى راس الخيمة، ونهض التعليم مع انثاء وزارة التعليم العالي عام 1991، وازداد التحاق البنات في التعليم العالي ووصل الى ــ ا9 طالبا في عام (") $1997 / 1990$

و واستحدث كليات التقنية العليا للطلاب والطالبات في معظم مدن دولة الامار ات لتأهيل

خريجين للتقنيات في مجالات الهندسة والادارة و التسويق. ثم افتتحت(جامعة زايد) عام 1991 لتلبية الحاجة العلمية والتربوية للطالبات على اسس اكاديمية رصينة، فضلا عن انشاء مؤسسات في التعليم العالي اخرى مثل(معهد الامارات للعلوم المصرفية)، و (مركز التدريب التابع لشركة نفط ابوظبي الوطنية)، و (مركز التميز للأبحاث التطبيقية والتدريب) لتوفير البرامج التعليمية، ثم

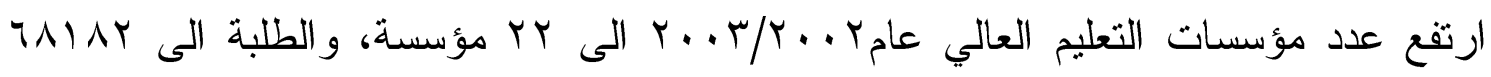

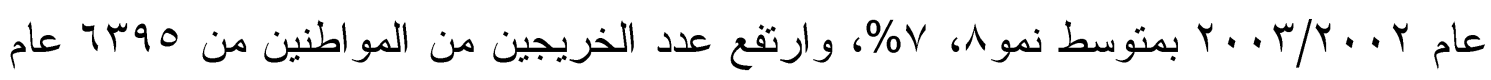

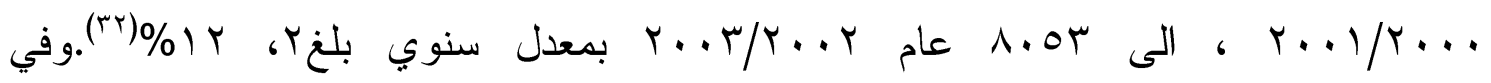
مجال(البعثات الدراسية) دعمت الدولة البعثات الدراسية وازداد عدد المبتعثين للخارج

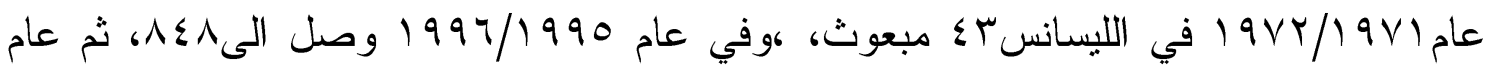

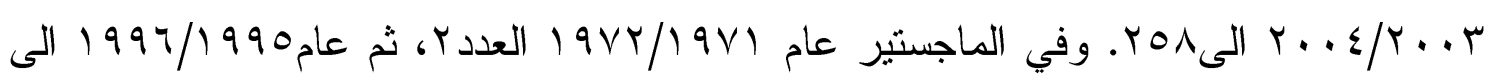

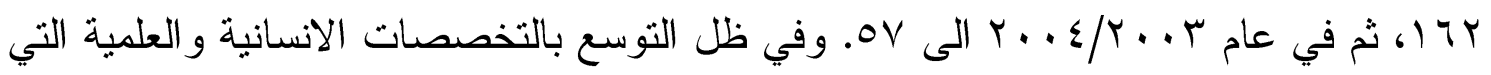
تحتاج لها الدولة في اتجاهات لأكثر من ^ی دولة خليجية وعربية واجنبية ابرزها الولايات

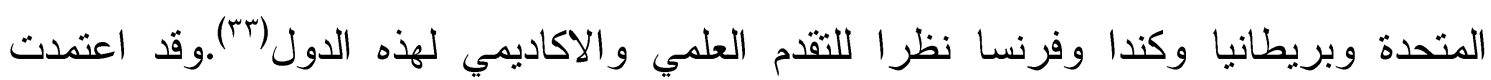
السياسة التعليمية الحديثة في دولة الامارات العربية المتحدة في التعليم العام او التعليم العالي على تعزيز اللغة الانكليزية الى جانب اللغة العربية لمو اكبة النطور العلمي في العالم، والاهتمام بالتقنيات الحديثة، ثم تبعها تقديم وزارة التربية والتعليم في تشرين الاول/اكتوبر ... . . مشروع

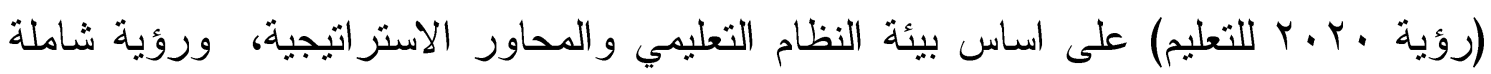


للمناهج و التدريسيين و المكتبات و التقنيات الحديثة والابنية التعليمية والتعليم الالز امي، ومكافحة

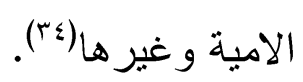

\section{Г. العنتصيات الثقافية والجوائز الملفية.}

عرفت دولة الامارات العربية المتحدة ظهور اندية وجمعيات ثقافية واجتماعية ومجالس ادبية والتي مثلت بدايات تأسيسها مر اكز للروح البدوية العربية يلتقي فيها رجالات الحي الواحد في المناسبات المحلية وملتقيات للاعيان و الثخصيات للحوارات في الشؤون العامة، و أسهمت هذه الملتقيات في بواكير الحياة الثقافية في مرحلة ما قبل اكتشاف النفط ثم ظهرت النخب الاجتماعية والمثقفة ور افقتها الجمعيات الخيرية وهيئات النفع العام من خلال الدعم الحكومي، ولها نشاطات مهنية ودينية وثقافية وهذه المنتديات برزت بوضوح في المجتمع الخليجي ومنها المجتمع الامار اتي بعد عام (9 (، و انعكست تأثثر اتها الثقافية والاجتماعية في العقود التالية(بr). وقد ظهرت بعد استقلال دولة الامارات العربية المتحدة عام ا9 اجمعيات ومؤسسات ثقافية تختص بالعمل الثقافي و الادبي، فضلا عن جمعيات اهلية تهتم بالثقافة وخاصة منذ الثمانينيات من القرن العشرين وما بعدها، وابرزها( دائرة الثقافة والاعلام) في الثارقة التي تأسست عام 1911 وتتظم العديد من الفعاليات الثقافية و الفكرية منها معرض الشارقة للكتاب السنوي ومهرجان الفنون الوطني وأيام الشارقة المسرحية وجمعية المسرحيين ومعهد المسرحيين ومهرجان الطفولة السنوي ومهرجان المسرح العربي ومهرجان مسرح الطفل ومسابقة الابداع الادبي للشباب، وبينالي الثارقة الدولي للفنون التشكيلية وتحولت هذه الدائرة الى مدينة ثقافية

و الشارقة امارة تحتضن الفعالبات الثقافية و الفنية و التطوعية و الاجتماعية(ج". اما في امارة ابوظبي، فتأسس( المجمع الثقافي) عام 919 ( كهيئة وطنية مستقلة عامسـة تلبيــة

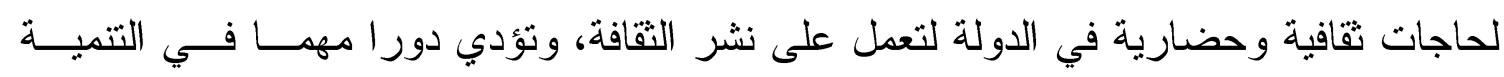
الثقافية كجزء من التتمية الثاملة ومن اهدافها رعاية النشاط الفكري و الابداعي واستخدام كافــة الوسائل المتاحة لتشجيع الحركة الثقافية ادبيا وفنيا و علميا على الصــعيدين المحلـي و العربـي و اقامة صلات ثقافية مع الجهات العالمية كما يضم المجتمع ثلاثة مؤسسات هي( مؤسسة الثقافة 
و الفنون) و(دار الكتب الوطنية) و(الارشيف الوطني) وحصل المجمع على جائزة شخصية العام

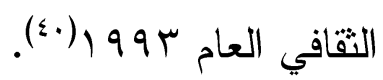
اما المنتديات الثقافية الاهلية في الدولة، ففي مقدمتها (اتحاد كتاب و ادباء الامارات) الذي نشأ عام ع 19 1 وله مكانته بين المؤسسات الثقافية في الدولة لنهوضه بالنتاج الادبــي و الفنـي، ونثـــر الابداع الامار اتي ورعاية المو اهب الثابة ، ويتخذ من مدينة الثـارقة مقر اله و اصدر عشــرات العناوين من نتاج الادباء و الكتاب، ونظم ندوات وملتقبات ثقافية بالتتسيق مع دو ائر الدولة مثـلـل ندوة الادب في الخليج، واسبوع الثعر الاول في الامارات، ويعقد الاتحاد اللقاء الاسبوعي في مقره في ابوظبي كل يوم اثثين، ومقره الاخر في الشارقة كل ثلاثاء(1)، واصبح عـام 1919 عضوا في اتحاد الادباء و الكتاب العرب، و اتحاد كتاب اسيا و افريقيا، وله دوريتين هما شــؤون ادبية ودر اسات، ومشروع جائزة سلطان بن علي العويس الثقافية وهي واحدة من ابرز الجو ائز التقافية في الخليج العربي و الدول العربية وحصل عليها مفكرين عرب بــارزين فــي الفضـــاء الثقافي العربي (ri). وقد اكد الشيخ زايد بن سلطان ال نهيان مؤسس الدولة على اهمية الكتاب بقوله “الكتــاب هــو و عاء العلم و الحضارة و التقافة... وان الامم لا ثقاس بثرو اتها المادية وحدها أنما تقاس بأصالتها الحضارية.... و الكتاب هو اساس هذه الاصالة..."، وعمل الثيخ زايد على ارساء دعائم الاهتمام بالثقافة من خلال المؤسسات الثقافية و المهرجانات ودور النشر و التـــراث وصـــانته وتدوينـهـ،

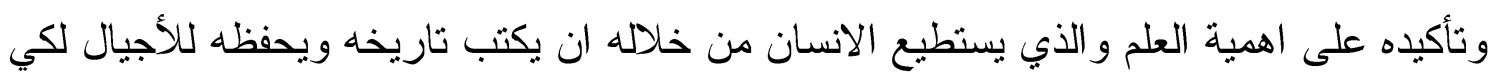
يطلعو ا عليه(r). ونشأت ايضا (جمعية التشكيليين) و (النادي العلمي بدبي) و (المجمع الثقافي و الاجتماعي بـدبي) الذي تأسس في عام سو ا و ويهتم بالآداب و التزاث، ومؤسسات خيرية مثل (مؤسسة زايد بـن سلطان ال نهيان للأعمال الخيرية والانسانية)، و التي اعلن عن نشأتها عام بو 199 هدفها اعمال الخير و البر و الاحسان و النفع العام داخل الدولة وخارجها و أنشاء مساجد ومر اكز تقافية اسلامية ومجامع البحث العلمي الاسلامي، والتعليم العالي و المكتبات العامة والمنح الدراسية وتبرعـات للجمعيات ذات النفع العام للجمعيات الخيرية و الانسانية(؛ ؛). 
و هناك (ندوة التقافة و العلوم) اسسها الادباء في عام 9NV و ومقرهــا دبــي، وهـدفها تشــيع المو اهب و الكفاءات ادبيا وثقافيا وتتشيط الحركة الثقافية ومنها الجـــوائز و المســابقات الثقافيــة السنوية مثل جائزة ر اشد للتفوق العلمي وجائزة شخصية العام الثقافيــة، وتكــريم الشخصــيات التقافية وتقديم جو ائز للبحث و الدر اسة(0؛). وتوجد جمعيات الجاليات و النو ادي كملتقبات تعبر عن هويتهم مثل جمعية الجاليات الهندية كجمعيات ذات النفع العام واشهار جمعيات خاصة بالجاليات منذ سبعينيات القرن العشرين مثل الجمعية الاردنية وجمعية سيدات مصر بــأبوظبي وجمعيــة بنغلادش بأبوظبي ايضا، و النادي الهندي في العين و النادي الهندي الاسلامي، ونادي مالايــالي ساماجام الهندي فضلا عن نادي جمهورية مصر العربية في عجمان و امارات اخرى، والنادي الاجتماعي السوداني في دبي وجمعية المر أة السودانية تأسس عام 9 أبأبوظبي، و المركـز التقافي الاجتماعي الصومالي تأسس عام 9VV (، وتمارس هذه الجمعيـات انثــطة اجتماعبــة وثقافية ونقابية تتعكس بطبيعة الحال على المشهد التقافي والاجتماعي في دولة الامار ات (؟v). وتعمل مر اكز بحثية في الدولة وتهتم بالتأليف و البحث و الترجمة في قضـــايا محليــة وعربيــة و عالمية من اهمها (مركز الامار ات للار اسات الاستر اتيجية) في ابوظبي وتأسس فـي ع ا اذار مارسع 99 1 بهدف نشر الدر اسات و البحوث و الكتب و ألقاء المحاضــر ات ونشــر الترجمــات العالمية لقضايا سياسية و اقتصادية و عسكرية و امنية و اعلامية عن مختلف القضايا العالمية، وفي مقدمتها قضايا تخص دولة الامار ات العربية المتحدة، ويحظى المركز برعاية ودعم الشيخ محمد بن زايد ال نهيان ولي عهد ابو ظبي. و الى جانبه هناك (مركز البحــوث و الدر اســات التـابع لوز ارة الثؤون الاسـامية) ويصدر مجلة منار الاسلام الفكريــة التــي تــوزع داخـلـل الدولـــة

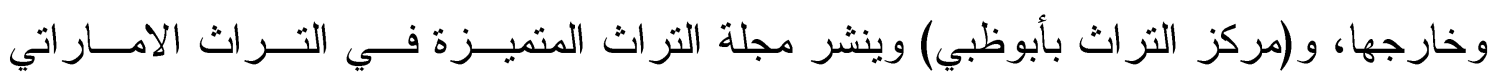
و العربي، و (مركز الدر اسات التابع لدائرة الاعلام بالثارقة) ويصدر مجلة الر افد الثهرية الثقافية و الادبية التي تحظى باهتمام وكتابة الكثير من الكتاب و الادباء العرب(^§). و هناك جو ائز اهتمت بالطفولة و الاعمال الابداعية الموجهة للأطفال مثل (جائزة الشيخة فاطنــة بنت هز اع بن زايد ال نهيان للمسيرة القصصية للطفل العربي)، و(جائزة الثيخة مبــر ا بنـــ هز اع بن زايد ال نهيان لشعر الطفل العربي)، و(جائزة لطيفة بنت محمد بن راثـــ ال مكتـوم 
لإبداعات الطفولة) وينظمها جمعية النهضة النسائية في دبي منذ عام 991 التتمية الابداع عند الطفل، و (جائزة غانم غباش للقصة القصيرة) وهي جائزة للقصة ينظمها النادي الاهلي بالتعاون مع اتحاد كتاب و ادباء الأمار ات وتحمل اسم المرحوم غانم غباش احد رواد الفكــــ الأهـار اتي، و (جائزة الصحافة العربية) لتكريم الصحفيين ورجال الاعلام ممن خدمو ا بلادهم، وهناك جو ائز تربوية وتعليمية تهتم بالمدرسين و الطلاب و المعلمين المتفوقين عالميا مثل (جائزة ر اشد للتنـــوق العلمي) تحمل اسم المرحوم الثيخ راشد بن سعيد ال مكتوم حاكم دبي السابق بتبرع من الثــيخ محمد بن راثد ال مكتوم تتظمها ندوة الثقافة و العلوم التي تأسست عام 911 التكريم المتفوقين علميا من ابناء دولة الامار ات العربية المتحدة، و (جائزة خليفة بن زايد للمعلم) وتحمل اسم الثيخ خليفة بن زايد ال نهيان رئيس الدولة لتكريم المعلمين ممن خدموا التزبية و التعلــيم ، و (جـائزة الثيخ حمدان بن راثد ال مكتوم للأداء التعليمي المتميز) وهي تربوية تهتم بالارتقاء في الاداء التعليمي وجائزة الثيخ خالد بن صقر للتفوق و التعاون الطلابي، و (جائزة الفهيم لتكـريم اوائـلـل الثانوية العامة)، و (جائزة عميد بن كنيش التعليمية)، وهناك جو ائز علمية اخرى متعـددة فـي الدولة وجو ائز عالمية من قبل مؤسسات نقافية وعلمية داخل الدولة متخصصة بقضــايا بيئ.ــة وطبية وضمان الجودة و العمل التطوعي وغيرها من المجالات الثقافـــة و العلميــة و الخيريـــة و النطو عية( (\$9).

\section{"ا.الصـافة والاعلام}

كان اهل الامارات بطالعون الصحف التي تأتيهم من الدول العربية وخاصة مصر عن طريق البواخر ومعها صحف من بغداد ودمشق وبيروت والكويت ، وعمل بعض السكان مر اسلين للصحف، ثم اخذ بعضهم بإصدار اوائل الصحف المتو اضعة في المدارس مثل (التيمية

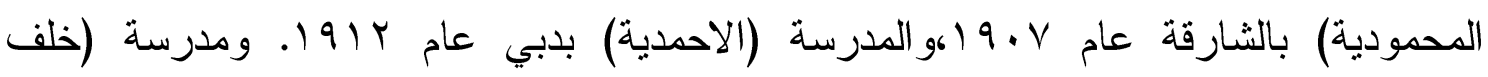
العتيبة) في ابو ظبي عام • بو ا. ثم قام ابراهيم محمد المدفع بإصدار (صحيفة عمان) اول

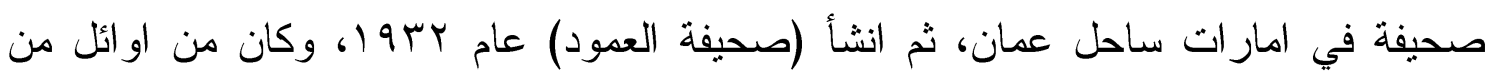
مارس الصحافة مصبح بن عبيد الظاهري الذي أسس (صحيفة النخي) عام عبها في مقهى بمدينة العين ويكتبها على اكباس الورق وسعف النخيل، واستمرت ستة عشر عاما متواصلة 
ترصد المجتمع الاماراتي وحركة القوافل التجارية وتتقل الاخبار من اذاعتي صوت العرب ولندن. وفي خمسينات القرن العشرين صدرت (مجلة الاتحاد البريدي) و (نشرة الديار)، ثم ثردي مجلة (اخبار دبي) عام 1970 1، والجريدة الرسمية في ابوظبي عام 1971 1، ثم صحيفة (الاتحاد) عام 1979 في العدد الاول في •r تشرين/ اكتوبر لتكون لسان حال الدولة ايام الدفاوضات على الاتحاد بين الثيخ زايد بن سلطان ال نهيان وحكام الامارات الاخرين، وكانت تصدر اسبوعيا وتوزع مجانا، ثم مع قيام الاتحاد وعام الو9 أصدرت (الاتحاد) وبدأت تصدر

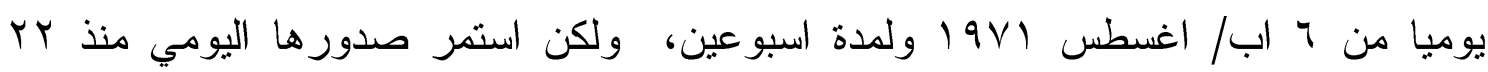
نيسان/ ابريل و I ا كجريدة رسمية يومية، ثم تبعتها بعد فترة الملاحق/ الرياضي/دنيا الاتحاد، ثم كانت رائدة عربيا في نقل الصحافة عبر الاقمار الصناعية عام ا919 (6وانشأت مطبعة ثانية في دبي لكن تطبع في ابوظبي ودبي، ثم دخلت عام الانترنت في 10 اذار/ مارس 1997 أكأول صحيفة محلية الكترونية(0.0. ثم صدرت صحيفة (الخليج) في العدد الاول في 9 انتشرين الاول/ اكتـوبر • 19Vا ومؤسســها تريم عمران واخوه عبد الله عمران ويتم طباعتها في الكويت آنذالك، ثم قرر الاخوين العـودة

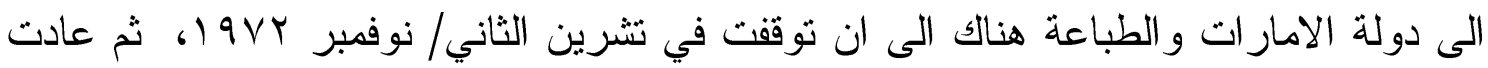

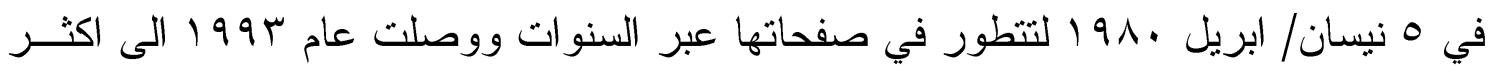
من . . أ صفحه مع الملاحق. وصدرت ايضا صحيفة (صوت الامة) فــي العـدد الاول عــام 9 19V0 ومؤسسها احمد سلطان الجابر وتحولت عام 19 الى يومية، ثم صــيفة (الفجـر)

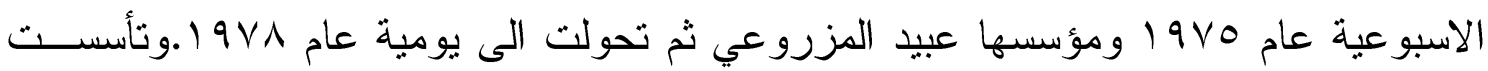
صحيفة (البيان) عام • 191 يومية من خلال مرسوم الثيخ راشد بن سعيد ال مكتوم (رحمه اله) في العدد الاول · ( ايار ، 191 ، وبدأت تصدر ملونة ونشأت لها مر اكز ابحاث مثل (مركـز

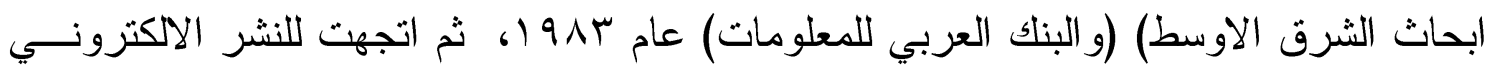

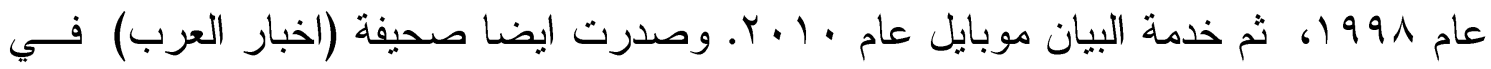
تشرين الثاني . . . يومية مستقلة مؤسسها الشيخ سعيد بن سيف الــ نهيان في ابوظبي ولهــا موقع الكتروني. و هناك صحيفة (جلف تايمز) بالإنكليزية وصدرت عام 9 19 عن دار كلداريي 
للطباعة و النشر وصحيفة (خليج تايمز) عام $9 \vee \wedge$ عن الدار نفسها بالإنكليزيــة، وصــحيفة (جلف نيوز) العدد الاول عام 9 اومؤسسها عبد الله ابو الهول رجل اعـــال، وصــدرت صحيفة (جلف توداي) عام 997 (عن دار الخليج بالإنكليزية، وصحيفة (ذا ناشــيونال) عـن مؤسسة ابوظبي للإعلام بالإنكليزية. اما المجلات فهناك الكثير منها التي صدرت في عهد الثيخ زايد بن سلطان الــ نهيان مثل (مجلة الشروق) اسبوعية عن دار الخليج عام • 9 ا، و (مجلة

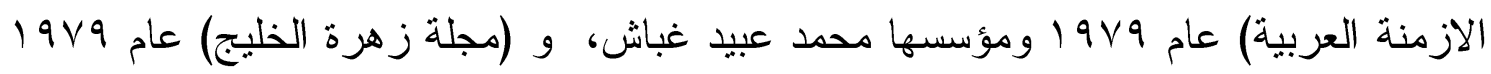
عن شركة ابوظبي للإعلام، و (مجلة كل الاسرة) عام سو91 عن دار الخليج، و(مجلة جواهر)

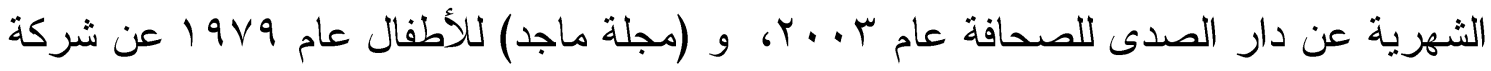
ابوظبي للإعلام، و (مجلة الاذكياء) عام 999 ( شهرية للأطفال، و (مجلة الظفرة) شهرية تعنى بالتر اث العربي و الامار اتي خاصة، و و(مجلة دبي الثقافية) وتعنى بالثقافة و الادب وتصدر عـن دار الصدى للطباعة و النشر، و (مجلة شهرزاد) شهرية وتختص بالمر أة(10. اما في مجال الاعلام، فقد بلغت تطور اكما ونوعا بشكل ملحوظ مع رؤيــة الدولــة بتحــرر الاعلام اذ حصلت زيادة كبيرة في المطبوعات والاصدار ات الاعلامية، وتم انشاء وزارة الثقافة و الاعلام في عام 9 1 الإشر اف على الاعلام الاتحادي والانشطة و الفعاليات الاعلامية فـي

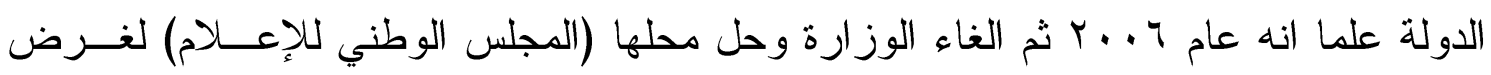
تطوير الاعلام، ودعم المبادرات الاعلامية كمرجعية اعلى رسمية للإعلام في الدولة. ومن جهة اخرى تبرز في المنطقة الاعلامية الحرة الاولى في منطقة الشرق الاوسط وهي مدينة الاعــلام

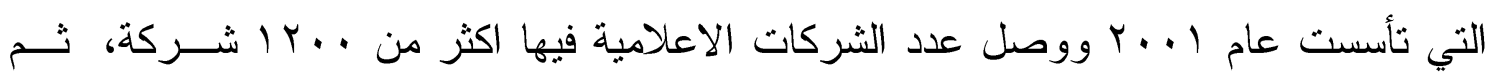
انتقلت الى دبي عدد من المؤسسات الاعلامية الكبرى مثل (محطة تلفزيون الثــرق الاوســط) MBC من لندن، ومحطات فضائية عربية مثل (العربية)، ومحطات امار اتية مثل (سما دبي)، (قناة ون) الانكليزية، (تلفزيون الشارقة)، (تلفزيون ابوظبي)، (تلفزيون عجمان) ومحطـات اذاعية تبث بر امج محلية وعبر الاقمار الصناعية(ه). بل ان هناك اكثر مــن قنــاة لأبــوظبي، رياضية وفنية ودر اما ايضا. وتأسست هيئات اعلامية مثل (وكالة انباء الامار ات) في تشـرين

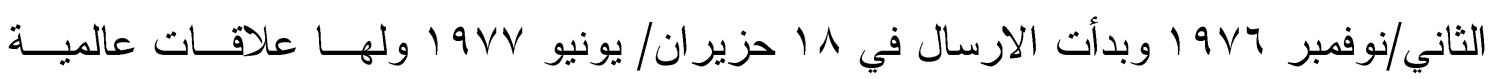


و عضوية في وكالات و اتحادات اقليمية و عالمية معنية وتبث اخبار ها بالعربية و الانكليزية ولهـا مكاتب داخلية وخارجية. و هناك (المجموعة الاعلامية العربية) تأسست عام V . . r فــي دبـي رأست مجموعات تجارية وخدمات اعلامية هندية وخليجية وهناك (اذاعات الاعلام المسـموع)

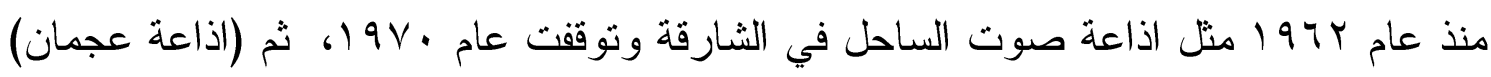
في مطلع ستينات القرن العشرين، (و اذاعة ابوظبي) في مب شباط فبر اير 979 (تأسست ثــ

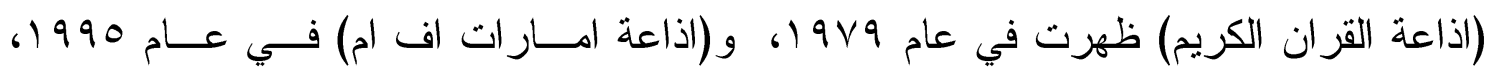

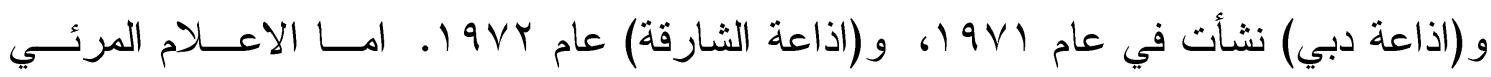
(التلفزيون، فكانت قناة ابوظبي) الاولى في الارسال في الدولة في اب/ اغسطس 979 (ا، وهي (تلفزيون دولة الامار ات العربية المتحدة) تبعتها (قناة ابوظبي الرياضية) عـام 979 المتابعــة الانشطة الرياضية، ثم (تلفزيون الامار ات العربية المتحدة) من دبي الملون عام • و9 وبـدأ البث عام (9V (، و (قناة دبي سب دبي ون) بالإنكليزية عام 9 (ا، و و(قناة دبي الاقتصادية)، و (تلفزيون الثارفة) في ((شباط/فبر اير 9 () ())، و (تلفزيون عجمان) عام 999 اوبــدأ البــث

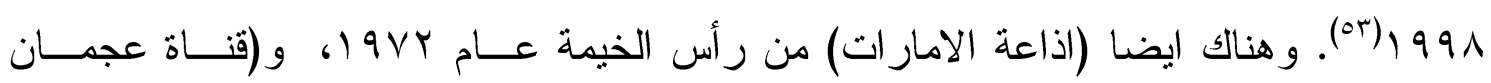
الفضائية)، و (تلفزيون الشارقة الفضائي) وكلها نهضت بالعمل الاعلامـــي و الفضـــائي داخـلـ الامار ات وخارجها في المحيط العربي و الاقليمي بل حتى العالمي(؛). و ان التطور و الانتاج الذي شهدته دولة الامار ات العربية المتحدة خلال الاربعين سنة الماضــية اتجه بالدولة منذ عهد الشيخ ز ايد بن سلطان الــــهيان وحكــام الامـــار ات للاهتمــام بالهويـــة و الشخصية المحلية باللغة و الدين مع العادات و التقاليد وربط الماضي التزراثـي مــع الحاضــر،

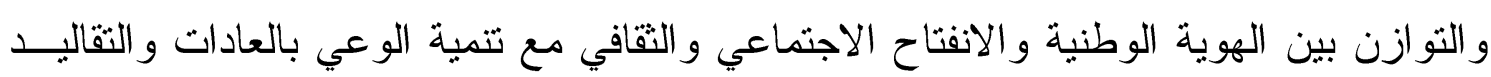
الاصيلة للدولة كالهجن و الخيول وحب الصحر اء و الزر اعة و الفلكلور الشعبي، و الحفــاظ علــى الاصـالة مع البناء على التعامل مع معطيات العصر خاصة في الاعلام و الميــديا الحديثــة(00). ويرى في ذلك الدكتور عبد الخالق عبد الله ضرورة تواصل الجيل القديم مع الجيل الجديد فـي تتمية المواهب الفنية والاعلامية في مرحلة الحداثة التي تحتاج دعم المؤسسات الثقافية الرسمية لتحقيق هذه النشاطات الثقافية ومؤسسات الاعلام الرسمي و الخاص(هن). 


\section{ع. المرأة والعمل الثمافي.}

احتلت قضية المر أة في مرحلة ما بعد اكتثاف النفط و التغير الاقتصادي والاجتماعي في المجتمع الخليجي عامه حيز الهاما لدى النخب المتعلمة و المنقفة في اطار تز ايد مطالب المرأة من اجل المشاركة في التعليم و العمل و الحياة العامة، ودخولها الى جانب الرجل في عملية التتمية و التحديث التي شهدها المجتمع الخليجي. وتزى الكاتبة الامار اتية الدكتورة ميثاء سالم الثامسي ان حالة النفط و التغيرات المصاحبة وحركة التنمية دفعت ان يكون للمر أة دورها ففي النهضة التعليمية والتقافية و المجتمعية مع ظهور التعليم الحديث، وتعدد الجامعات و المعاهد العليا، وتغير القوانين و التشريعات الاجتماعية وظهور الاندية و الجمعيات الخيرية و التطوعية ومنها النسائية،

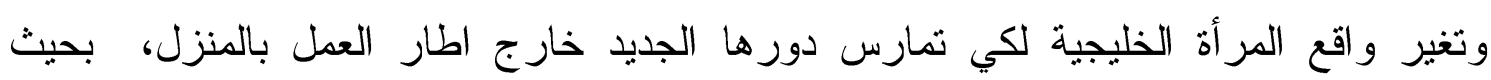

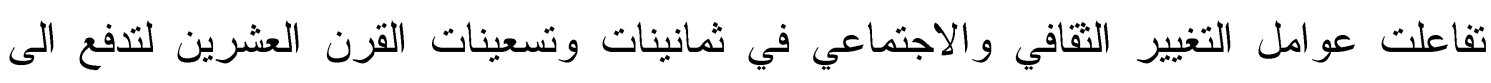
تغيير و اقع المرأة مع حركة التحضر والتركيبة السكانية الجديدة بفعل الهجرة الوافدة التي

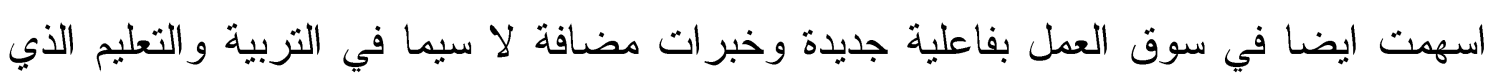
دخلت فيه المر أة(م).

وقد تجسدت البدايات في الجمعيات النسائية التي ظهرت في دولة الامارات العربيـــة المتحــدة بفضل الدعم و التشجيع الذي قدمه الشيخ زايد بن سلطان الــ نهيان و هدفه ان تكون للمر أة دورها

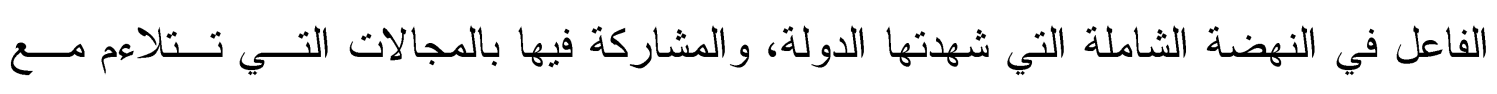
قابلياتها. وجاءت البداية مع (جمعية النهضة النسائية في رأس الخيمة) عام لو 197 ثم (جمعيــة

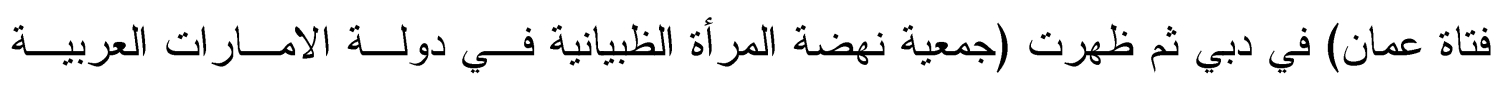

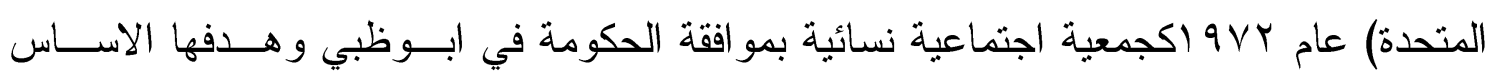

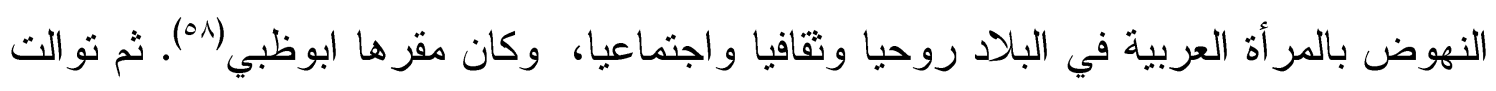
فروع الجمعية وفي الثارقة وام القيون وعجمان منذ عام ع 19V، و وحظيت برعاية حرم رئيس

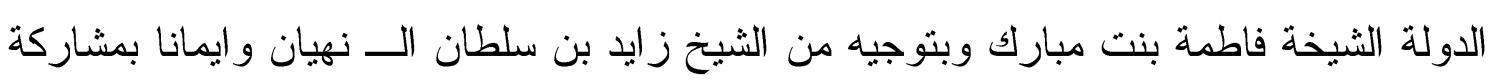

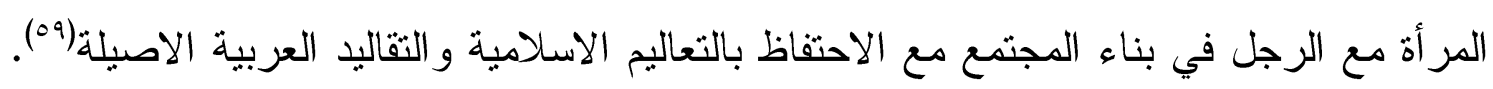

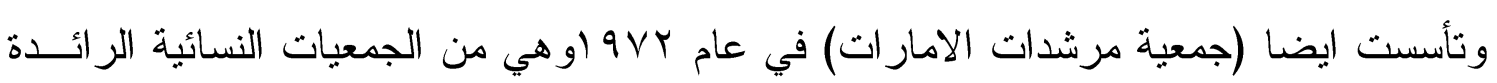


في دولة الامار ات العربية المتحدة في رعاية المر أة دينيا وثقافيا واجتماعيا و علميا وصحيا مسنـ خلال بر امج لتطوير ها والتي تتلاعم مع قيم المجتمع المحلي، وحظيت الجمعية برعاية الثـــيخة جو اهر بنت محمد القاسمي حرم الثيخ سلطان القاسمي الر اعية للجمعية، وعملت علـى تنظـــم الاندية الشبابية و الجمعيات العاملة في رعاية الشباب من خلال مفوضيات في الدولة موزعة في ابوظبي و الشارقة ور أس الخيمة والفجيرة من خلال الاسس العامة للحركة الكشفية والارشادية، و الحفاظ على الهوية الوطنية و العمل التطوعي للفتيات في كافة الامار ات(·"). وبمرور الــزمن تصاعدت الحركة النسائية في دولة الامار ات في الجمعيــات و الاعمــال التقافيــة والخيريــة، ونهوض المر أة في التزبية والتعليم و العمل و الاعلام، وحققت المر أة الامار اتية خلال عهد الثيخ زايد بن سلطان الـــ نهيان قفزة كبيرة ونوعية في كافة المجالات لتساهم فـي عمليــة التنميــة الثاملة التي عرفتها الدولة و لاسيما خروج المرأة الى ميادين العمل، وارتفع المستوى التعليمي للمر أة ووصل عدد المواطنات الحاصلات على الثهادة الجامعية الى اكثر من (ب الف) عــام

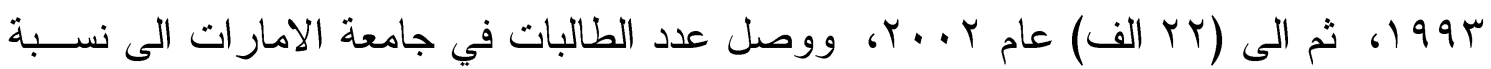
\% من اجمالي عدد طلبة الجامعة، وازداد عدد الحاصلات على الشاهدة العليا فـي الــدبلوم و الماجستير و الدكتور اه في التخصصات الانسانية و العلمية ووصل عام / . . . . . . اللى نسبة \% VV النسائية في الدولة عندما قامت وزارة الثؤون الاجتماعية بالإشر اف على عملها في عام ع بصفة رسمية ثم تأسس (الاتحاد النسائي العام) الذي ضم جميع الجمعيات النسائية فــي الدولــة

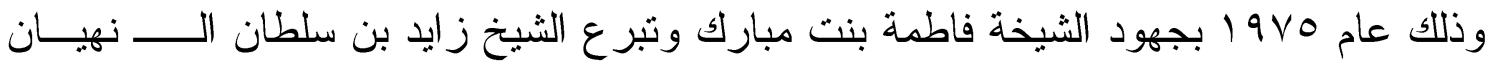
ببناء مقر دائم للاتحاد في ابوظبي ومقر كل جمعية نسائية في الدولة، ثم انضم هذا الاتحاد الى

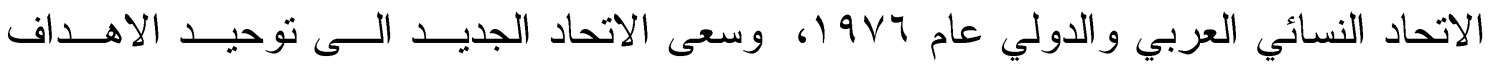
و النشاطات و الاستفادة من الخبرات و التجارب للجمعيات النسائية وخدمــة الاعمـــال الخيريـــة و الاجتماعية ومشاركة المر أة في مسيرة الثقافة والعلم و التعليم في الدولة وتطوير قدرات المرأة الامار اتية وتأهيلها اذ خصص الثيخ زايد بن سلطان الــ نهيان ميز انية مستقلة للاتحاد النسائي الى جانب ميز انية لكل جمعية لوحدها. ثم اعلن في عام 1990 عن تأسيس (نادي السيدات فـي 
ابوظبي)، ووصل عدد الجمعيات الى (9) في الدولة، حصلت على نسبة (, •r\% مــن قيمــة

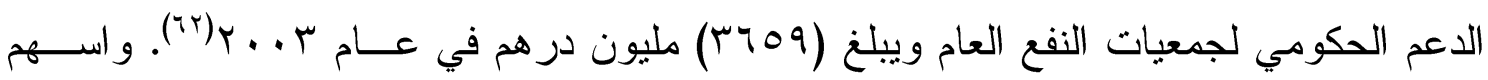
الدعم الحكومي للدولة لهذه الجمعيات النسائية الى ان تسهم في رفع مستوى مشاركة المر أة فـي المجتمع في التوعية الدينية وقضايا المرأة و الانرة و العمل ومحو الامية و الطفولة وتعليم الكبار

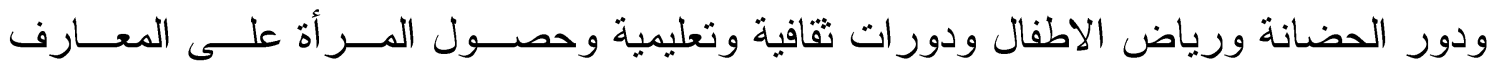
و الخبر ات مع ازدياد الاقبال النساء على هذه الجمعيات بحيث وصـلـل فـي عــام 1990 الــى (11 ( (1)عضوة في جميع هذه الجمعيات لتسهم المرأة في عملية التتمية و النهوض بالمجتمع في دولة الامار ات العربية المتحدة("ج)ثم تجسدت وثيقة (الاستر اتيجيات الوطنية لتقدم المرأة في دولة الامارات العربية المتحدة) كمرحلة مهمة في العمل النسائي في الالفية الثالثة وهي من اسهامات الاتحاد النسائي المهمة ودشنتها رئيسة الاتحاد النسائي العام في لا اكانون الاول/ديسمبر ب ...؟، وشارك في اعداد الوثيقة الاتحاد النسائي العام والفرق الحكومية وغير الحكومية والامم المتحدة، وتعد نقلة نوعية للنهضة النسائية في الدولة إذ سعت الاســتراتيجية الــى تفعيـل دور المــرأة ومشاركتها في التعليم و الثقافة و التربية و العمل و الاعلام و الصحافة و العمل الاجتماعي و الصحة

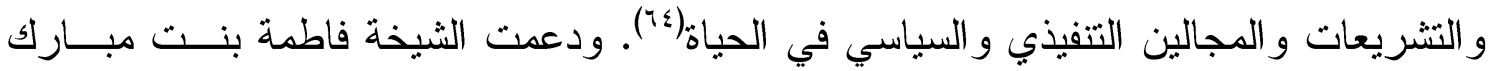

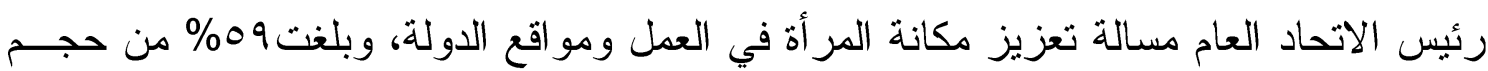

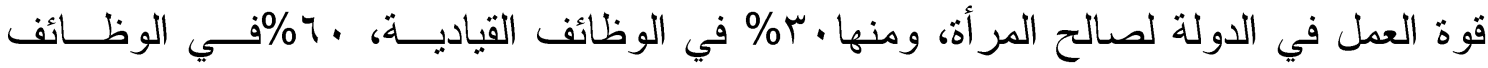

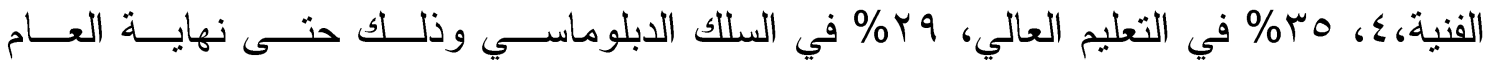

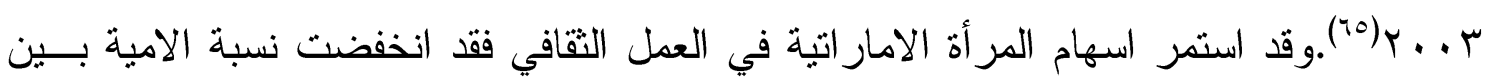

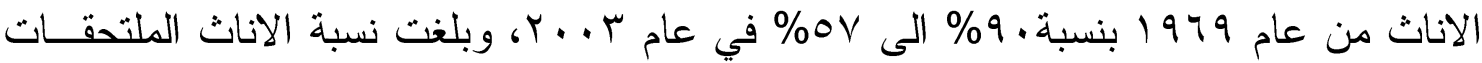

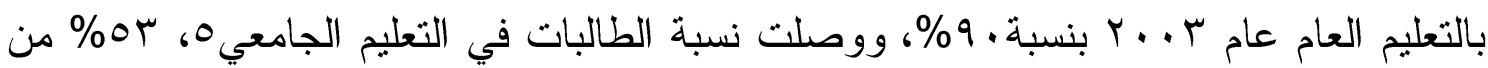

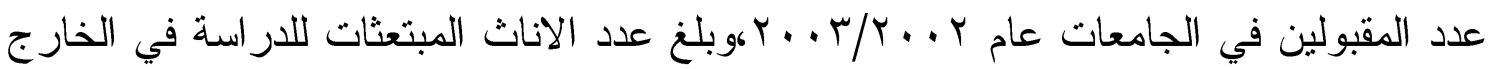

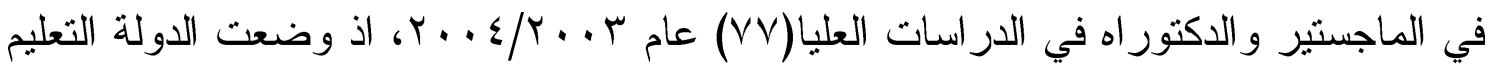
كأولوية لها في عملية التتمية، ووصلت المر أة الى مناصب وكيل وزارة، ومناصب دبلوماســية وعضوات هيئات تدريس في الجامعات، ثم في عام ا... حصلت نقلة نوعية للمر أة في تمثيلها 
في المجلس الاستشاري الوطني لأمارة الثارقة في (0) سيدات وحضور هن جلسـات المجلـس

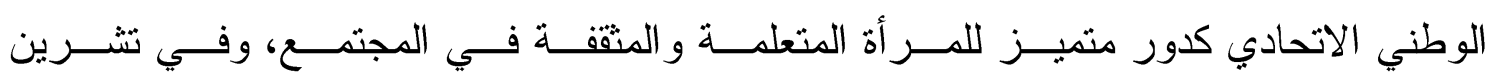

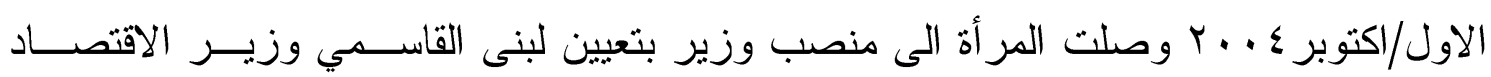

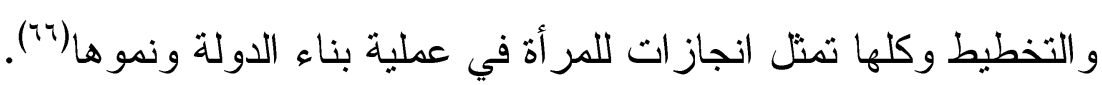
0. التراث الثظافي الشعبي. عرفت دولة الامار ات العربية المتحدة تقاليد وعادات وموروثات شعبية ارتبط بها الحياة الاجتماعية مع الثقافة الشعبية حالها حال بقية دول الخليج العربي الاخرى، ومن بينها ثقافة مجتمع ما قبل اكتثاف النفط في ظل حياة بسيطة ومنها(رياضة الصيد)، والقنص البري باستخدام الاسلحة البرية في الصحر اء وهناك تجري حفلات الاعياد و الاعر اس ومعها رقصات البدو بالسيوف والخناجر، فضلا عن الاحتفالات الدينية والوطنية والرقصات الثعبية للبحرة والاهازيج على السفن او الغوص على اللؤلؤ ، وصيد الاسماك في اطار نقافة شعبية بسيطة

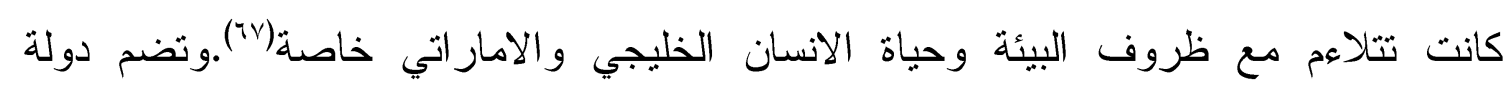
الامار ات العربية المتحدة تجمعات انسانبة في الساحل و الواحات و البادية في تتوع التزاث الثان التقافي

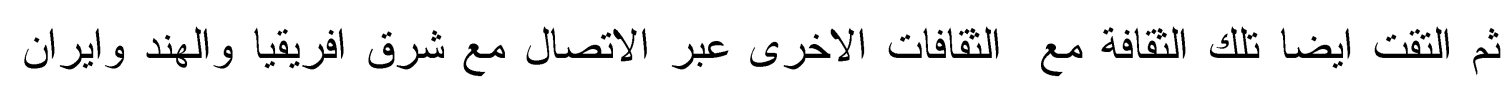

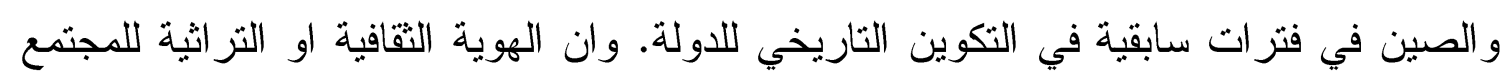
الاماراتي تعتمد على مهن الاباء والاجداد الرواد ومنها الصيد التي لازالت الناس يعتمدوها

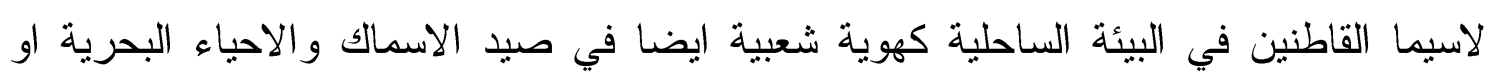
صيد الطيور البحرية. اما في المناطق الريفية في صيد الطيور البرية كالحمام والصقور والتي تعد هو اية ورياضة لاسيما لأبناء البادية الذين يخرجون الى الصحر اء لاصطياد الحبر ويطلقون

$$
\text { صقورهم على(طيور الحباري) لاصطيادها(1). }
$$

وتعد (الصقارة) نز اث انساني حي ونشاط تقليدي يعتمد اصطياد طريدة بو اسطة طائرة جـار ح

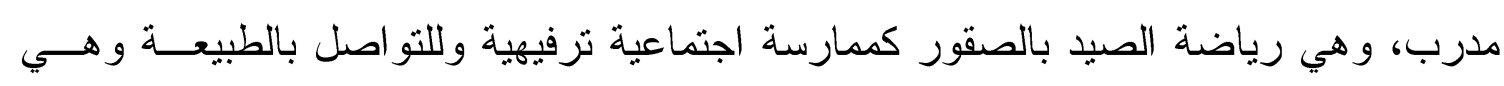

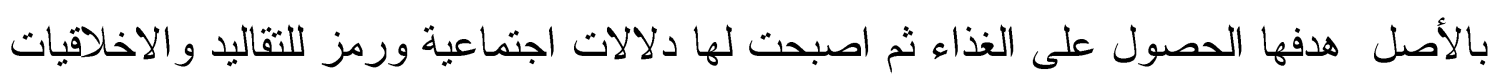
ذات الطابع الثقافي. وتمثل(الصقارة) ربط الانسان بالطيور وهي قديمة وتعتمد على اطلاق صقر 
لاصطياد طريدة في بيئتها الطبيعية من افراد في مختلف الاعمار، ومع مرور الزمن تطــورت العلاقة بين الانسان والطيور و اصبحت هناك لغة خاصة بين الصقر والصــقار وبــرز الادب الشعبي تمثل في الشعر و الامثنال و الاغاني و القصص و الحكايــات وتطـــورت ادوات الصــقارة اليدوية. وتتميز (الصقارة) كمجموعة تمارس الرياضة التراثية و القيم الثقافية على التعاون و الدعم المتبادل وتسمى رابطة المخوة(الاخوة) في دولة الامارات العربية المتحدة، و الر ابطة (الثــريك) في المملكة العربية السعودية وتتمثل في رو ابط الصداقة و المشاركة و المهام و المسئولية في رحلة صيد لمجموعات التي تتراوح بين(آ-Y ( ) صقار ا في ممارسة الرياضة التراثية ومعها جلسات

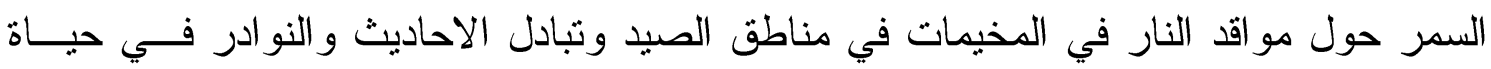

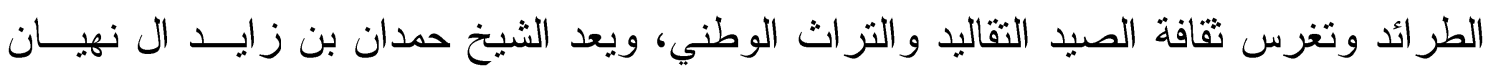
رئيس نادي صقاري الامارات، علما ان هذه الرياضة الثعبية تعلم الانسان ثقافة الصبر وحسبـ البيئة و الار ادة و الاخوة، وتتنقل من جيل الى اخر فهي تراث دولة وشعب واسهم الثيخ زايد بن سلطان ال نهيان في دعم وترسيخ ورعاية هذه الرياضة الى ان وصلت الى تسجيلها في القائمة

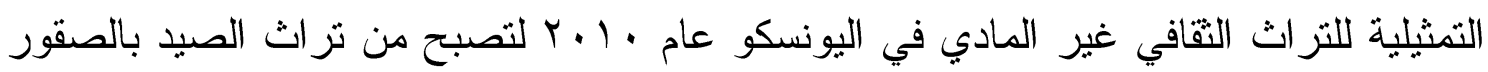
دلالة على اهتمام الدولة بالتزاث عامة والتزاث الثقافي غير المادي(19). وفي مجال (الحرف و الصناعات الثقليدية) فهي الاخرى تشكل جزءا مهما من المأثورات الشعبية

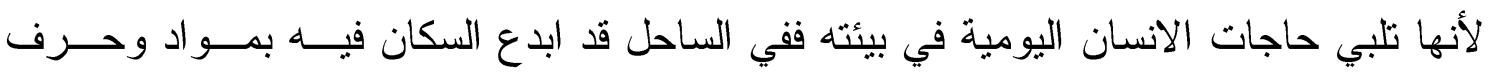
ركوب البحر وسكان البادية لهم مهن خاصة بالصحر اء، اما سكان الريف و المناطق الزر اعبــة فالسكان يقومون بحرف الزر اعة والرزق وتعد الحرف و الصناعات التقليدية من الموروث الذي تبنته(هيئة ابو ظبي للثقافة و التراث) كمشروع انتاج وتطوير الحرف و الصناعات التقليدية للحفاظ عليها و هذه الحرف مارسها سكان الدولة في الماضي و لاز الو ا يمارسون بعضها مثل صــناعة سعف النخيل و الخوص(السفافة) السلة-الجفير، المزماه، المهفة، المشــب، الجراب(الخصــف)،

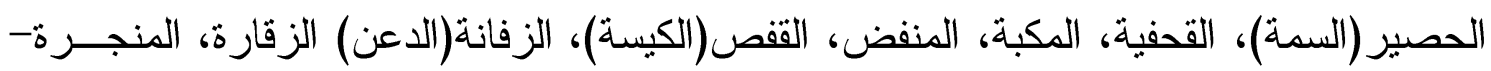
الثاشة، الحبل، الحابول، التعصيم، العريش، الخلابة، التجديع. اما في صناعة النسيج و الحياكــة وغزل الثعر فهناك السدود، بيت الثعر الزربول، الثُداد، العدل، الخطام، الخناقــة، الســقاع 
البطان، اللثام، السامة، التلي، الكندورة، السروال، الطربوشة، البشت، البرقع، البادلة، الثـــراع. اما في صناعة الاخشاب فهناك المندوسن الابو اب، النو افذ، السفن، المر اكب، الجلافة، التحطيب، الطبل، الفحم. وفي الصناعات الجلدية فهناك الدباغة القربة السعن الظرف الدلو النعال السـقى لــ المحزم.وفي صناعة الحدادة المحماس السكين الداس المسحل المسحاة المخلاب المطرقة العتلــــة السيف الدلال الملقط المنشار .وفي صناعة الفخار هناك الحب، البجلة، الخرس، المبخرة، التنور، الاو اني. وفي الزينة الكحل و اللبن. في مهن اخرى هنالك صيد الاسما، وصيد اللؤلؤ، و الزر اعة،

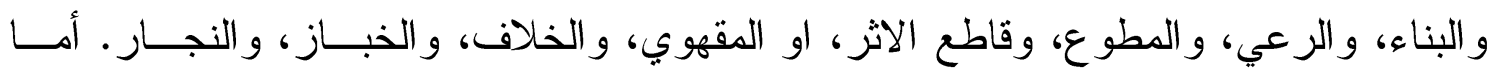
صناعة الحلي فهي الذهب و الفضة. وفي الطب الشعبي الكي، والحجامة، و التجبير، والحـــواج، و التزفيح (')

وتمثل (الحكاية الثعبية) نمطا اخر من انماط التزراث الثُبي في المجتمع الاهــار اتي وتعـرف ب(خروفة) اذ يجتمع الاطفال اما الجدة او الام للاستماع الى الخروفة للتسلية و المتعة و الفائسدة

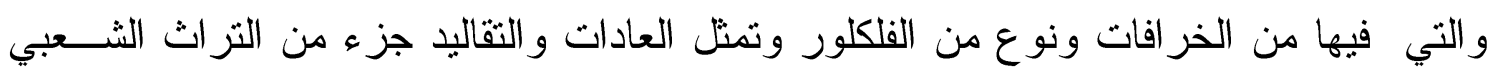
داخل الاسرة من الاجداد و الاباء الى الابناء، وتتقل الحكايات الثعبية القيم و المثل العليا من جيل الى اخر، وصياغة روح ثقافة المجتمع مع الامثال الثعبية والاعر اف والاغاني الثعبية باللهجة الخليجية مع بعض السجع وعبار ات طريفة تترك مكانتها في نفوس الاطفال، ومن بــين اثــــر

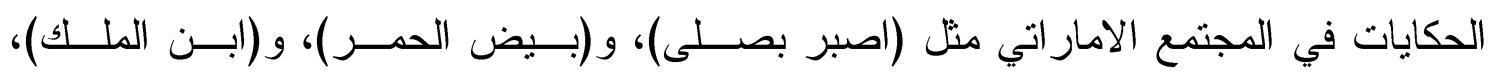
و (البديحة)، و (كركمة) و (حب ميثا)، و (موزة و الساحر)، و (جبل الفرج)، و (سيسان وخريسان)، و (ام الضروس). وتمثل الحكايات الثعبية وسيلة مهمة لنقل العادات و التقاليد و المتل العليا و اللغة من جيل الى اخر، وترسيخ الثقافة الشعبية في نفوس الاطفال وهي ثقافة امار اتية وخليجية وقيم

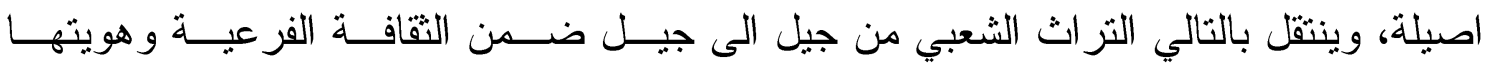
المحلية(Vr) ان رؤية دولة الامارات العربية المتحدة وسعيها للحفاظ على التراث الثقافي وحمايته وتعزيــزه من خلال وضع استر اتيجية الحفاظ على التراث الثقافي بالتعاون مع مؤسسات محلية وعربيــة

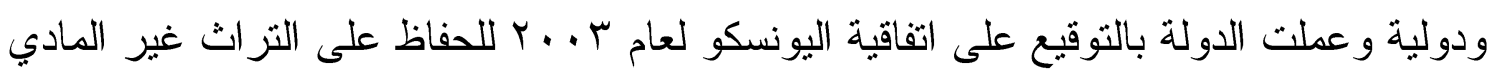


وصيانته، فضلا عن ان (هيئة ابو ظبي للتقافة و التراث)تتظم فعاليات ثقافية وتر اثية لتأكيد هـــه التوجهات مثل(معرض روائع التزاث الشعبي فير المادي)، و(جائزة الثيخ زايد بن سـلطان ال نهيان لروائع التراث الثفهي وغير المادي للإنسانية)(rr). وقد اتجهت الدولة برعاية هذا التزاث الثقافي منذ عام 19 أبتأسيس (لجنة النزاث و التاريخ) في عدة امارات حتى انهت اعمالها عام 991 ا، و انجزت مشروعات لتوثيق التزاث الثقافي كالثعر الثعبي وتراث النخيل و الطب الثعبي و الابل و الامثال و الحكم و العادات و التقاليد،

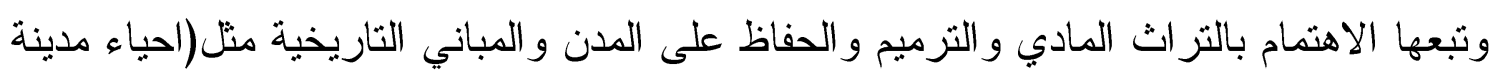
الثارقة القديمة) والاهتمام ببقية الامارات، ومع اهتمام بهذا التراث المادي افرز اهتماما شعبيا بالتزاث التقافي من الزي الثعبي ومجالس البيوت ومجالس العريش ومجالس العرب التقليدية و غيرها. ثم ان(المتاحف) حظيت باهتمام الثيخ زايد بن سلطان ال نهيان و افتتح عام 941 الفي في مدينة العين اول متحف بالدولة، وتو الى بعدها افتتاح المتاحف في كل امارة من الامار ات بحيث

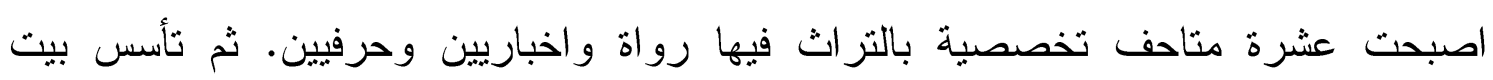
الموروث(مركز التراث غير المادي) فرقا للجمع الميداني وباحثين في التراث التقافي والتاريخ الثعبي والارشيف السمعي و البصري وصور قديمة ووثائق ومراسلات وتتظم الادارة ندوات

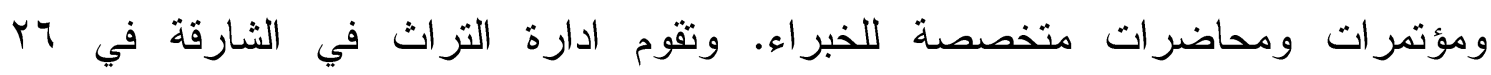
شباط/فبر اير من كل سنة بالاحتفال بهذا اليوم بوفاة احد انشط الرواة في دولة الامارات العربية المتحدة وهو الراوي راشد الثوق تقليدا سنويا لتكريم الرواة والحرفيين ثم نقوم الادارة (بأيام الثارقة التزاثية) تزامنا مع يوم التراث العالمي في \1 من نيسان/ابريل من كل عام تحتفل

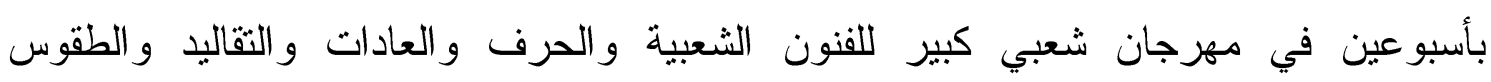
و المأكو لات و الالعاب الثعبية. أما(مسارح التراث الثقافي) فقد اهتمت بها المسارح في في الدولة كجزء من التزاث الثقافي المادي وغير المادي من الازياء ولهجات ومأثثرات صوتية وحركية وفنون و العاب شعبية وطقوس ونصوص ومسرحيات مستوحاة من التزاث الوطني الامار اتي (عال). 


\section{ר. الفن التشكيلي والمسبرح.}

يمثل الفن التشكيلي بكل عناصره من الرسم والنحت والتصميم والعمارة، وهو جزء من تقافة الانسان وممارساته اليومية وصلة بين الفنان و الناس وجزء من البيئة التي يعيش فيها الانسان ورسالته النبيلة. و عليه فان الفن التشكيلي في دولة الامارات العربية المنحدة يملك الكثير من الفنانين التشكيلين ممن اسهموا في صناعة الفن التشكيلي الاماراتي في الخارطة الخليجية و العربية مثل نجاة مكي وعبيد سرور وابر اهيم العوضي وعبدالرحيم سالم ومحمد يوسف الحمادي و هشام المظلوم وعبدالقادر محمد الريس وحسن شريف ومحمد مندي. وتعد نجاة مكي وايز من اعلام الحركة التشكيلية الاماراتية ولها مشاركات محلية وخارجية وعضو في جمعية

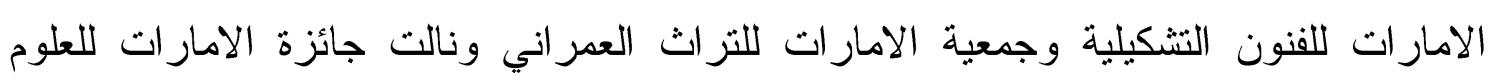
و الفنون والآداب عام V... r.اما عبيد سرور فهو مؤسس جمعية الامارات للفنون التشكيلية وشارك في معارض محلية وعربية وهو مهتم ببيئة النخيل والشواطئ والعمارة القديمة. آما ابر اهيم العوضي فهو مؤسس مع اخرين جمعية الامارات للفنون التشكيلية ويهنم بالرسوم ذات الدلالات التراثية الاهلية للأمارات، وله مشاركات محلية وخارجية وفاز بجائزة بنيالي الثارقة

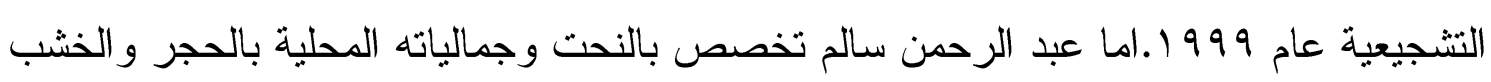

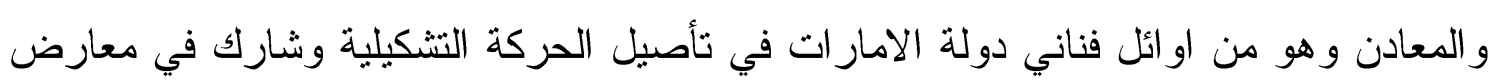
محلية وخارجية وحصل جائزة الامار ات التقديرية للعلوم و الفنون والآداب فرع الفنون التشكيلية عام ^ .. ب.ومحمد يوسف الحمادي المهتم اكاديميا بالفن التشكيلي وتز اس مجلس ادارة جمعية الامار ات للفنون التشكيلية ثم تراس ادارة مسرح الثارقة الوطني وهو بركز في اعماله على البيئة و الحركة و السكون ونال العديد من الجو ائز منها جائزة الامار ات الثقديرية في مجال الفنون

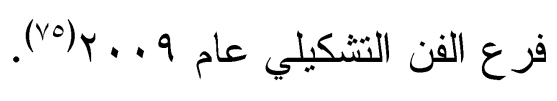

اما هشام مظلوم فهو احد اعمدة الحركة التشكيلية في الدولة وصمم الملصقات وشعار تلفزيون الثارقة ومونديال اسيا عام 199 المدينة الثارقة للخدمات الانسانية وجمعية حماية اللغة العربية ثم عين مظلوم مدير اللفنون في ادارة الثقافة والاعلام بالثارقة وهو متخصص بالتصميم الجرافيكي.ويعد الفنان عبد القادر محمد الريس من ابرز التشكيليين الاماراتين واشتهر خارج 
الدولة كفنان محترف وشارك في العديد من المعارض الداخلية والخارجية ويركز في اعماله على الانسان والوطن ونال جوائز عربية واجنبية منها جائزة الدولة التقديرية للعلوم والآداب و الفنون في مجال التصوير والرسم عام ؟ ...r. و وايضا في نفس الاطار يمتل الفنان حسن شريف علما من اعلام الفن التشكيلي في دولة الامارات ويعمل في مدينة دبي وقد اسهم الى جانب زملائه في نهضة المشهد الفني الامار اتي وهو من اعلام الفن التشكيلي برؤيته الحداثوية و واسس مرسم الفن في مسرح الثباب في دبي وجمعية الامارات للفنون الجميلة ومجموعة الخمسة واعماله في الفنون البصرية ومؤلفاته في الفن الجديد ومشاركاته في المعارض لهري الخارجية. أما محمد مندي فهو الخطاط في الزخرفة و الخط العربي وشارك في معارض عربية و اجنبية وعمل في تصميم الثعارات الخاصة والرسمية و المسكوكات وكتابة الاوراق النقدية للاول العربية وفاز في مسابقة حمد الله الاماسي في الخط الكوفي (نَ"). اما في مجال المسرح والحركة المسرحية فأن دولة الامارات العربية المتحدة كجزء من دول الخليج العربي اسهم فيها المسرح في مرحلة مهمة في التغيير الاجتماعي والثقافي في

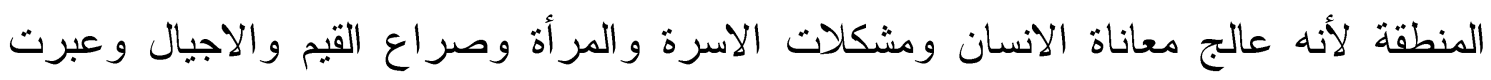
الاعمال المسرحية عن تفاعل الانسان مع المسرح فاصبح تدريجيا للمسرح شعبية ومكانة منميزة

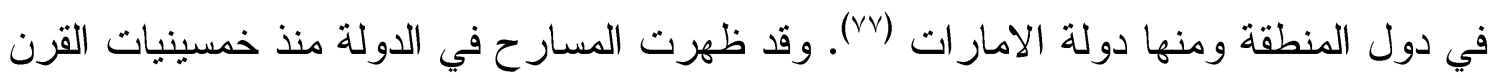
العشرين فشهدت الثارقة اول مسرحية في النادي العماني وفي عام 1901 قدم (نادي الشعب في الثارقة) مسرحية نهاية صهيون باكورة اعمال الثيخ سلطان بن محمد القاسمي، ثم في دبي عرضت مسرحية في المدرسة الاحمدية في العام نفسه اسمها جامع الذهب، واسهمت الاندية

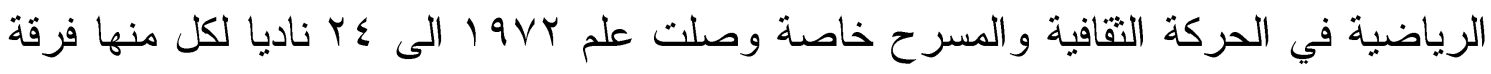
مسرحية. ففي الثارقة نشكلت فرقة مسرحية في نادي الثعب ونادي العروبة وفرقة مسرحية في النادي الثرقي و النادي العماني. في دبي تأسست فرقة مسرحية بنادي الثباب و النادي الاهلي، وفي ابو ظبي فرقة الثرطة المسرحية، وفي عجمان تأست فرقة مسرحية لنادي الناصر، وفي راس الخيمة فرقة مسرحية في نادي عمان. وبهذا الاتجاه وفي العيد الاول لقيام الاتحاد في 
الدولة نم تقديم (اوبريت حكيم الزمان)و (اوبريت الاتحاد) حضره الثيخ زايد بن سلطان ال نهيان ومعه حكام الامار ات الذي قال فيه: "...علينا ان ننظر الى الور اء لنرى كيف عشنا وكيف صبرنا وكيف واجهنا الصعاب ونصيحتي ان تقبلو الصر احة وتقبلو النقد.....

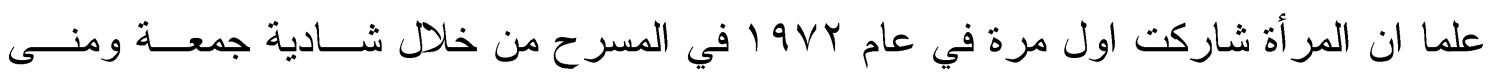
مبارك ثم تثجعت تدريجيا وشاركت في المسرح كل من موزة المزروعي ورزيقــة الطــارش

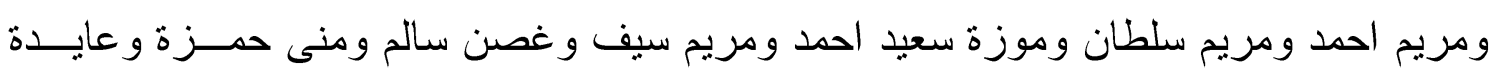

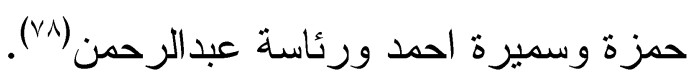
ان تطور المسرح الامار اتي في سبعينيات القرن العشرين ثم الانتعاش في النصف الاول من ثمانينيات القرن ذاته ادى الى نضوج الحركة المسرحية في العقد التالي. و لاسيما ان تاريخ المسرح وصل مرحلة مهمة منذ عام 19 أحديدا بوصول الخبراء المسرحيين وهم صقر الرشود من الكويت و ابر اهيم جلال من العر اق ثم المنصف السويسي من تونس، اذ حصل تطور كبير مع تأسيس قسم المسرح في وزارة الاعلام والثقافة اسهم في استقطاب مسرحيين اخرين مثل خليفة العريض وعبدالكريم عوض وغيرهم، وازداد عدد المخرجين العاملين في الاخراج المسرحي من العراق والكويت ودولة الامارات العربية المتحدة ومصر و السودان و البحرين وتونس وسوريا والاردن، واسهم المسرحيون الاماراتيون في كتابة المسرحيات متل ابراهيم بوخليف واحمد بوسالم واحمد عبدالرزاق و اسماعيل عبداله وحمد سلطان وسالم اكطي وسعيد حداد وسلطان الشاعر وعبداله عمران تريم وعبداله الثرع وعبدالحميد احمد وعائشة الكابتن وعمر عبيد غباش وعلي الثالويي وفاطمة لوتاه وغيرهم، ووصل عدد الممتلين الى بـ بـ ممثلا في الدولة والعناصر النسائية الى عب ممثلة، ومن اهم الكتاب الذين مثلت اعمالهم في المسرح الامار اتي الدكتور ابر اهيم البصري و الفريد فرج وتوفيق الحكيم وحنا سعادة وحسين ابو المكارم وخلف احمد خلف وخليفة العريضي وسعداله ونوس وسعد الدين وهبة وصلاح عبد الصبور

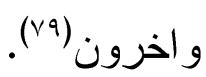


وعمل المسرح المدرسي في دولة الامار ات العربية المتحدة منذ عام بو ا في حقـلـ التربيــة و التعليم بجهود مسرحيين ومشرفين بالأعداد و الكتابة و الاخر اج و المعالجة المسرحية في قضــايا وموضوعات تاريخية ووطنية ومن بين هؤلاء المسرحيين مهرة القاســي ونــوره الثامسـي وفاطمة لوتاه و عبد المنعم عو اد ومحمد قناوي ويوسف الشريف وحيدر ادريس ونعيم الر اعـي و اخرين، ثم اخذ المسرح المدرسي منذ عام 9 ا يقدم اعماله المسرحية في تلفزيون دبي التي اسهمت في الاعمال المسرحية المتميزة بحيث اتجهت وزارة الاعلام و الثقافة في الدولـة فـي ثمانينيات القرن العشرين ضرورة التعاون مع وزارة التربية بأرسال عبداله الاســتاذ وابـر اهيم بوخليف لدر اسة المسرح في (المعهد العالي للفنون المسرحية في الكويت) وتخرجـــا فـي عــام س^و 1 ،و عين الاستاذ رئيسا لقسم المسرح وبوخليف مسؤو لا للقسم في امار ات الثــمال. ثــم تو الت البعثات الدر اسية خار ج الدولة لدر اسة المسر ح الى الكويت و الو لايات المتحـــدة اذ تميــز المسرح في هذه المرحلة للعمل الاكاديمي و الجامعي من خلال مسرحيين منـل حسـن رجــب وجمال مطر و ابر اهيم سالم ومحمد الدوسري وغانم عبيد غباش و علي العبدول ويونس الخاجــة و عدنان بخيث وقيس محمد الر اشد وحميد سمبيج وحبيب غلوم(.^). اما الفرق المسرحية التي ظهرت خلال هذه المرحلة في دولة الامارات فهي مسرح الامار ات القومي ضمن قسم المسرح في الوزارة ويضم عدة فرق تشارك في المسرحيات خارج الدولة، وفرقة المسرح القومي للشباب عام 19 I و اعلنت في العام التالي وكان مقرها دبي وقدمت اوبريت الاتحاد وشاركت في مهرجانات داخلية وعربية وتضم 0Y عضو ا فيها وفرقة جمعية الشارقة للفنون الشعبية في المسرح الحديث عام ؟VV و وقدمت عدة مسرحيات ثم تغير اسم المسرح الى فرقة المسرح الحديث في الثارقة عام 1919 ،وفرقة مسرح خورفكان الشعبي من قبل وزارة الشؤون الاجتماعية في عام $19 \vee \wedge$ ونظمت الفرقة في عام 9 و في عدة مسرحيات قصبرة الاعياد و المناسبات ثم عرض مسرحيات ذات ابعاد اجتماعية هادفة. وتأسست فرقة مسرح ام القيوين عام 9 ا لتببع جمعية الفنون الشعبية قدمت اعمالها المسرحية منذ عام 9 و ا ثم انفصلت عن جمعية الفنون الثعبية في ام القيوين في وقت لاحق. وظهرت فرقة مسرح الفجيرة القومي في امارة الفجيرة عام 9 19 
وقدمت اعمال مسرحية في الامارة في قضايا اجتماعية ووطنية وتأسس ايضا مسرح ليلى للطفل عام س1911 وقدم اعماله في عام 1910 بهدف نشر الوعي والثقافة والتعاون مع مسرح الطفل وعرضت مسرحياته في التلفزيون المحلي. وهناك مسرح الاتحاد في ابو ظبي ثم مسرح الثرطة في ابو ظبي بعد ذلك وقدم العديد من المسرحيات التي اسهمت في نهضة الحركة المسرحية الاماراتية. ثم برزت الفرق المسرحية الجامعية مثل( فرقة المسرح الحر) في مدينة العين وهو مسرح جامعي منذ عام 1919 و العاملين فيه هم الطلاب الذين عملوا للنهوض النه بالمسرح داخل الجامعات. وأيض( فرقة مسرح الثارقة الوطني) من خلال الفنون الثعبية و المسرح في الثارقة وبثت المسرحيات في تلفزيون ابو ظبي ثم تأسس مسرح الثارقة رسميا عام 19V7 باسم المسرح الوطني بالثارقة و اشهر رسميا عام 1971 تحت اسم مسرح الثارقة

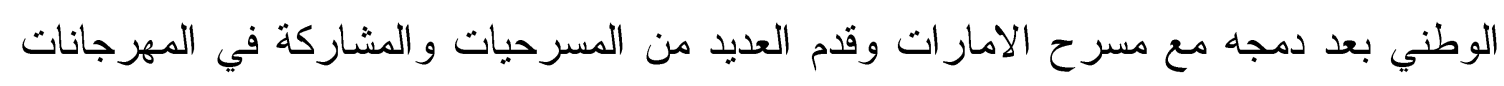

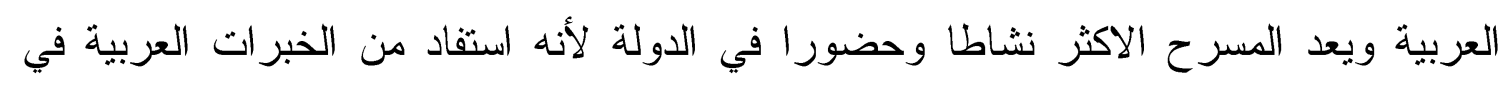
اعماله. ثم تأسس (مسرح صقر الرشود براس الخيمة) عام بلو9 الوقدم العديد من المسرحيات

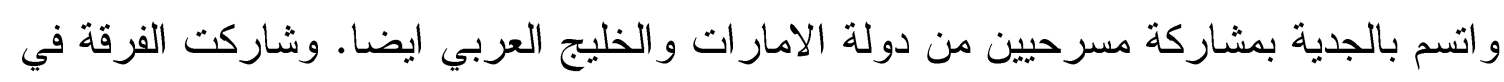

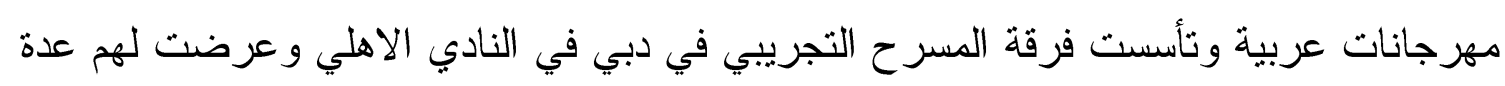

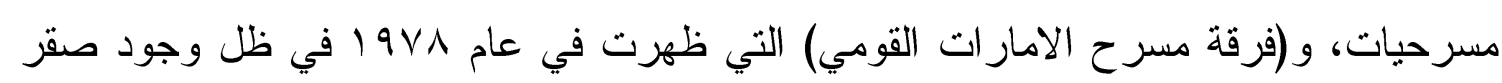

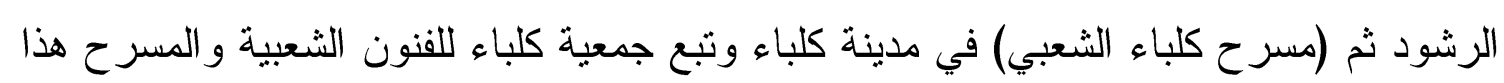
ظهر عام 197^ ونقل اعماله الى الثارقة وقدم العديد من المسرحيات، وبرز (مسرح النادي الوطني للتقافة والمسرح في عجمان) عام 1979 في نادي الثعلة وقدم اعماله المسرحية القصيرة. و هناك (مسرح عجمان) وتابع الى جمعية عجمان للفنون الثعبية التي ظهرت في عام 19VV و وكانت مسرحياتها محدودة، و(مسرح الشرطة) الذي تشكلت منه منذ سبعينيات القرن

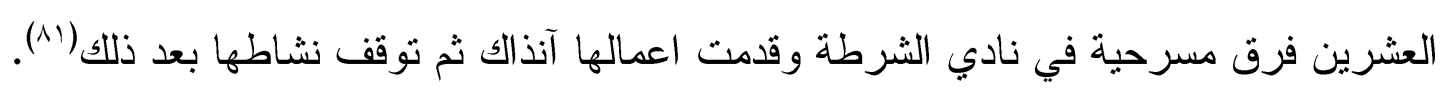

\section{U العركة الأصبية.}

اهتم الادباء و الكتاب في دول الخليج العربي بقضايا اجتماعبة من هموم الناس والصلة بين

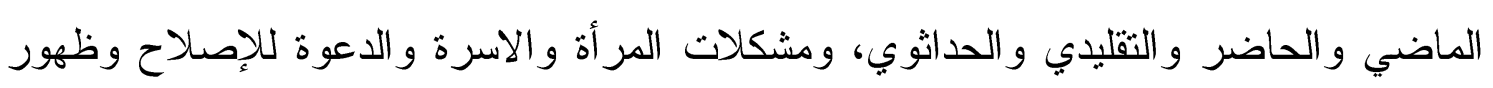


نتاج ادبي يعتمد التراث الثعبي والعادات و التقاليد، ثم بعد اكتشاف النفط والحياة الجديدة و التغيرات الاجتماعية و الاقتصادية اتجهت الكتابات الادبية نحو قضايا ليست محلية فحسب بل عربية و عالمية وبروز اقلام نسوية تخص الكتابة في قضايا مشكلات المر أة في المجتمع وترجمة نتاجات اجنبية و انتقلت بالتالي رؤى عالمية الى المجتمع الخليجي وتجلت سمات الادب الخليجي عامة في القرن العشرين بدعواته للإصلاح و التجديد في قضايا التربية والتعليم و الديمقر اطية و التحرر وقضية المرأة بحيث كان الادباء الاوائل هم المصلحون والمربون والمعلمون دعاة للتجديد في المجتمع(r). ثم تلى تلك المرحلة وفي ستينيات القرن العشرين ظهور التعليم النظــــي وبــو اكير الصـــافة وبروز القصيدة التفعيلية لتجارب عربية مع ظهور تجربة الدكتور احمد امين المدني الذي درس في بغداد و عاد بتجربته لبقدم اهتماماته للقصيدة التفعيلية و اصدر عـدة دواويـن منها(حصــاد

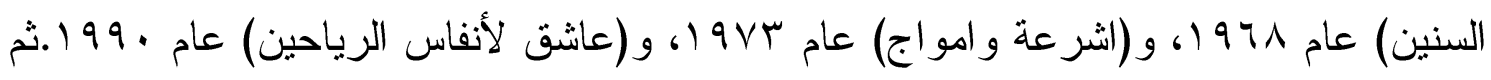
برز شعر اء ايضا مثل عارف الشيخ ومانع سعيد العتيبة وحبيب الصايغ الذين عملوا على تجديد الرموز الشعرية في قصيدة التفعيلة و اصدروا عدة دواوين شعرية. و الى جانب هؤلاء الشــعر اء ظهر تيار محافظ مثلك سلطان خليفة الحبتور وحمد بو شهاب وشهاب غانم ، ثــ ظهـر تيــار تجديدي حديث في الكتابة الشعرية مثله ظبية خميس و عارف الخاجة ونجوم الغانم واحمد راثد ثاني وخالد بدر عبيد وميسون صقر وحصة عبداله وامين عبدالعزيز وليلى احمد ومنى ســـف و هالة حميد معتوق وخالد الر اشد وجعفر الجمري، و انحاز من جانب اخـر العنصــر النســوي الادبي الى التجديد في الشعر و القصة القصيرة. وظهرت في ثمانينيات القرن العشرين اســماء ادبية اخرى مثل عبدالعزيز جاسم و عادل خزام وثاني السويدي وكلثم عبدالله وكــريم معتــوق

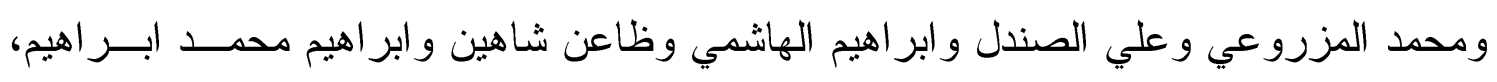
وتميز هذا الجيل بالانفتاح على اشكال جديدة في الكتابة الادبية ومعاصرة التحولات في المشهد الشعري و الادبي العربي (ع^).

وكانت الدولة و على رأسها الشيخ زايد بن سلطان ال نهيان راعية للحركة الادبية وخاصة الشعر و الشعر اء، اذ كان الشيخ زايد نفسه من رموز الحركة الشعرية في دولــة الامـــار ات العربيــة 
المتحدة في جانب الثعر الثعبي ودعمه الدائم لتطوير الثعر وتتجيعه الادب والادباء، وتبعـهـ حكام الامار ات في دعم الشعر اء فكانت هناك مجالس ومنتديات ومركز نقافية فــي ابــو ظبــي و الثارقة وبقية الامار ات اعطت الثعر اهتماما كبير اوقامت وزارة الاعلام و الثقافة والمؤسسات الثقافية بطبع الدواوين الشعرية على نفقتها وتشجيع ودعم الشعر اء وتوزيع الدواوين على الدو ائر الحكومية في الدخل و المؤسسات الثقافية في الخارج مجانا للتعرف على النتاج الادبي الامار اتي.

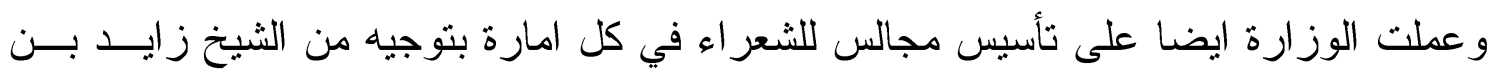
سلطان ال نهيان ودعمها ماديا ومعنويا من اجل الابداع الثشعري وتـــــتـح ابــواب الاعــلام و التلفزيون و الاذاعة امام الثعر اء مع دعم المؤسسات الادبيـــة و الثــعرية و النقديــة وتشـــيع المؤسسات كافة في الدولة لتطوير الادب الامار اتي. وشهدت مدن ابو ظبي ودبي و الثارقة وبقية

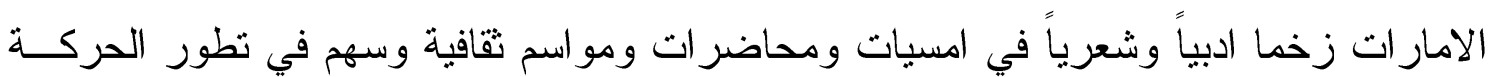
الشعرية و الادبية (10).

ويعد (الثعر النبطي) ذو مكانة خاصة في المجتمع الخليجي وخاصة في دولة الامارات

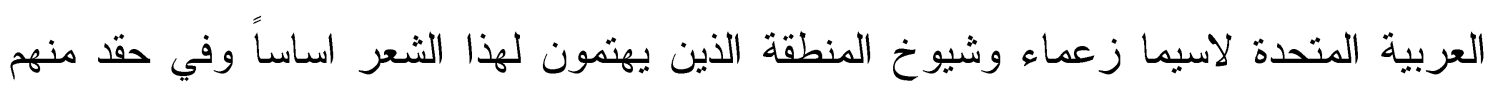
الشيخ زايد من سلطان ال نهيان وصدرت قصائد ودواوين ومخاطبات بشعره وهو محب للشعر

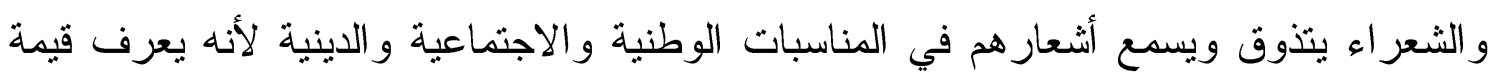
الثعر، وجاء اهتمام الثيخ زايد بهذا اللون من الثعر له تأثيره المباشر في نظور الشعر في

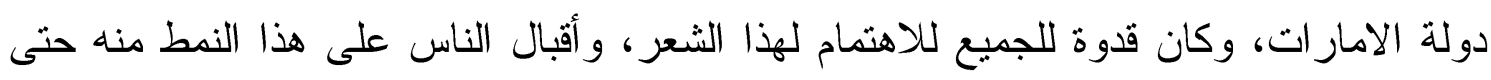
من لا يقر أ و لا يكتب اذا يستخدم العفوية في القاء الشعر النبطي شفاهاً في المجالس و المنتديات تنتقل بالذاكرة من شخص الأخر، ومن جيل الأخر وقد سعى الثيخ زايد الى حفظ التراث

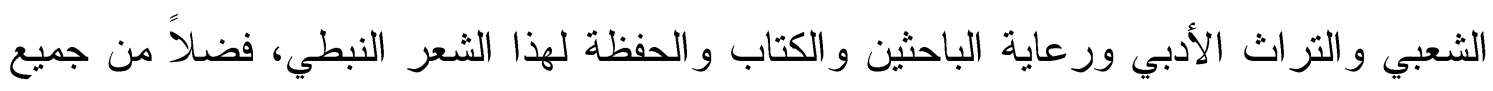
وتدوين الثعر الثعبي تكون ذاكرة حية تبقى للأجيال القادمة، ومن أبرز الدارسين الشاعر حمد أبو شهاب و الدكتور فالح حنظل (من العراق) ومقيم في دولة الامارات، والذين كتبوا التراث الادبي ودونوه من القديم الى الحديث من الشعر، وحققوه في إصدارات أدبية وشعرية، وكتب

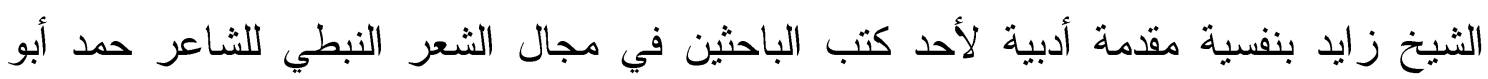


شهاب في كتابه (تراثنا من الشعر الشعبي) وصدر عن مؤسسة الاتحاد للصحافة والنشر عام VAV ا، اذ كتب الثيخ زايد بقوله: "الأمة التي لا ماضي لها هي أمة بلا حاضر ولا مستقبل، وقد كاتت امتنا ... والحمد لله غنية بماضيها التليد، وحضارتها الزاهية الضاربة بجذورها في اعماق هذه الأرض...." (ז^). أما العنصر السنوي، فأدى دوره في الحركة الأدبية في دولة الامارات في النزعة الاحتجاجية المطالبة بفك العزلة عنها و العمل الى جانب الرجل، ودخول مجال التعليم والخروج من المنزل ومشكلة الزواج و الطلاق والاختلاط والاغتراب المجتمعي والمربيات الاجنبيات وكلها مشكلات واجهتها المر أة الخليجية عامة ومنها الامار اتبة ايضاً، وكتبن قصصيات و أدبيات في هذا الاطار مثل أمنية بوشهاب وسلمى مطر ومريم جمعة فرج وليلى احمد وظبية خميس وصالحة غباش وسارة النواف وامينة عبداله وشيخة الناخي وابتسام المعلا وليلى أحمد وباسمة محمد يونس. ويعد من ابرز المؤسسات الادبية في دولة الامارات العربية المتحدة هو (الاتحاد كتاب و ادباء الامارات) و الذي يحتضن الادباء في مختلف مشاربهم الابداعية من شعر وقصة ور اوية وقصة قصيرة ونقة، وله نشاطين ثقافيين اسبوعياً هما (نادي القصة) و ( نادي الشعر)، ويشرف على جائزة سلطان بم علي العويس، وجائزة غانم غباش ويهتم في اصدار المنشورات من القصص و الروايات والنقد والتزاث و المسرح وكتب الاطفال و الفنون والثعر و المجلات الأدبية، ومقره في مدينة الشارقة ويمنل مختلف الأدباء في الدولة من الثمال الى الجنوب، وفيه منتسبين من الدول العربية مصر وسوريا والاردن ولبنان و الكويت و البحرين، ويسعى للارتقاء بالأدب و الكتابة الأدبية في الدولة، وتشجيع لكل التراث العالمي الى اللغة العربية، وتوطيد العلاقات مع الاتحادات الأدبية والعالمية، ورعاية المواهب الثبابية في الدولة وصقل قدر اتها وتظويرها، ودعم تتشيط الحركة الثقافية وتتسيق الجهود مع الاتحادات المهنية والثقافية داخل الدولة وخارجها، ومن بين ابرز الأدباء في هذا الاتحاد عبد الفتاح صبري (مصري) وعائشة عبداله وطلال سالم وحبيب يوسف الصايغ واسماء علي الزرعوني وابر اهيم الهاشمي واحمد عيسى العسم وباسمة محمد يونس ومحمد راشد المزروعي وعبدالله محمد السبب وناصر العبودي، ويصدر الاتحاد مجلات (شؤون أدبية) و (در اسات) و (بيث السرد) و (قاف). (^v). 


\section{خاتمة}

تعود الحركة الثقافية في تجلباتها المبكرة في امار ات ساحل عمان الى أواخر القرن التاسع عشر والنصف الأول من القرن العشرين في ظل التعليم البسيط والمدارس الدينية والشعر الثعبي و البدوي، ثم تحولت الحباة بعد اكتثاف النفط و التغير الاجتماعي و الاقتصادي اللى بزور

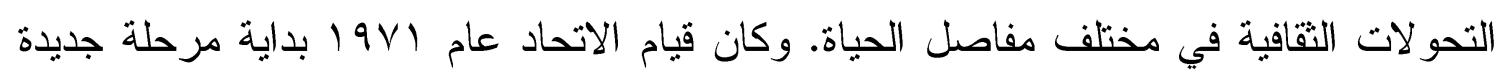
في هذه التحولات بالتمسك في التراث الثقافي كأساس للنهضة الحديثة الدولة الامارات العربية المتحدة رغم الحداثة وحركة العمران والبناء التي شهدتها في المجالات الاقتصادية والمالية، ومو اكبة عصر التكنولوجيا الحديثة والعولمة التي اصبحت بها الدولة في طليعة الريادة الاقليمية و المنافسة العالمية. ولم تكن المرأة الامارتية ببعيدة عن هذه التحولات فانطلقت نحو التعليم العالي و البعثات الدراسية و الدخول الى التعليم و الدر اسة في مختلف التخصصات ثم شقت طريقها نحو الصحافة والاعلام والاندية و الجمعيات الخيرية و الثقافية و الدسرح و الحركة الادبية والفنون

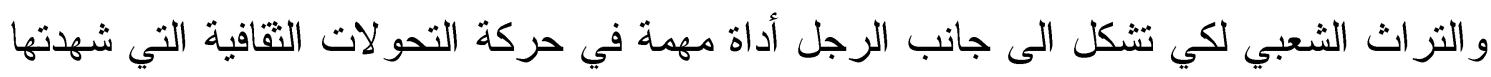
دولة الامارات و لاز الت حتى الوقت الحاضر ـ وقد انطلقت الدولة منذ العقدين الاخيرين كمحطة للأرسال الفضائي و الاعلامي وللقنوات الفضائية المحلية و العربية، ومركز أللندوات و المؤتمرات

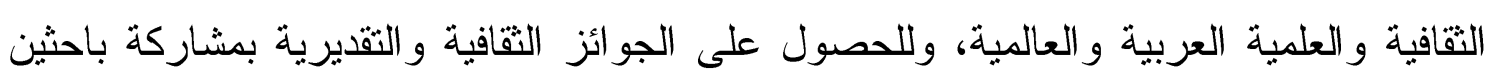
ومفكرين من دول العالم المختلفة لتأخذ الدولة مكانتها العربية والعالمية وتربط بين الانجازات الاقتصادية و المالية والتتموية و التحو لات الثقافية.ومن مميزات الثقافة الامار اتية تأكيد الثيخ زايد بن سلطان آل نهيان ومن بعده حكام الامارات على أهمية التراث الثعبي في بناء الانسان

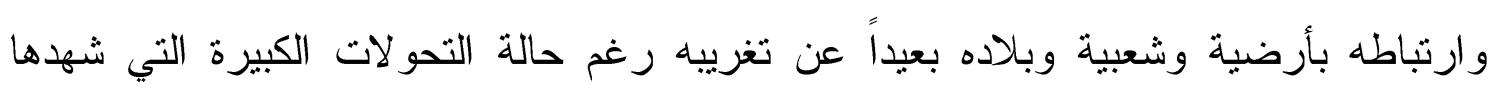
المجتمع، فظهرت ابداعات ثقافية في الحكايات الشعبية و الحرف و الصناعات و البيوتات التاريخية و الرقصات الثعبية والقلاع والاثار الوطنية والمتاحف في ظل رؤية وطنية برعاية التزاث

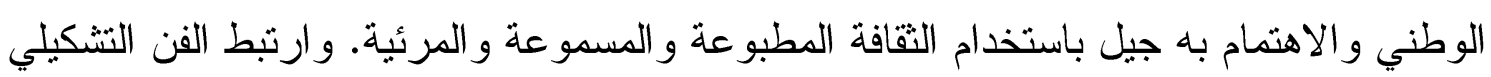
بهذه التحولات في الدولة برؤية محلية وعالمية بظهور ابداعات فنانين محليين اسهووا بهذه التحو لات في اعمالهم ونتاجاتهم. أما المسرح الاماراتي فتجسد بروح المجتمع والانسان الجديد 
في الدولة ما بعد الاتحاد والنهضة الجديدة في الدراسة و البحث الاكاديمي والتأليف والكتابة و التمثيل و الاخر اج في رحلة طويلة امتدت الى عدة عقود يشكل المسرح كعماد للحركة الثقافية في الدولة ويعبر الى المحبط الخليجي والغربي.ولم يكن الشعر بأنماطه النبطي و الشعبي

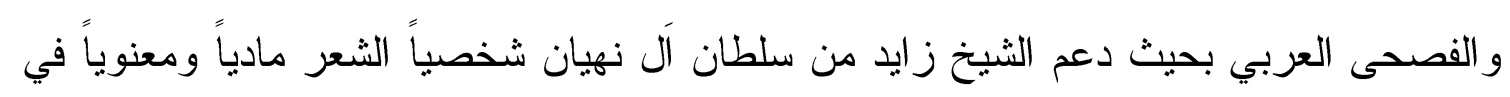
انشاء المجالس الشعرية في جميع الامارات ودعمها رمزاً للأصالة ودلالة على الروح البدوية و العربية الاصلية لمصلحة الأجيال القادمة، فظهرت المنتديات الأدبية التي رعت الادباء و الباحثين و الكتاب بالتو اصل مع النخب العربية التي أسهمت في ظهور الأدب الامار اتي من خلال نتاج تتوعت مشاربه بالمحاضرات والكتب و الدراسات و المجلات و الترجمات العالمية و الدواوين الشعرية، والقصة القصيرة والرواية والانماط الادبية الاخرى، ولتشكل كل هذه الانجازات حالة من التحولات الثقافية في الدولة تكوين التجربة الامار اتية غنية عربيا واسلاميا لكونها اقامة نهضة تتموية شاملة ليست مادية بل استتدت الى الاصالة و التراث، ولم تتسلخ عن جذور ها الثقافية وهويتها التراثية و الاسلامية رغم تسار ع حركة العولمة وتجاذباتها العالمية. 
1. عائشة محمد المحياس، الامن الوطني الداخلي الدولة الامارات العربية ، طا،

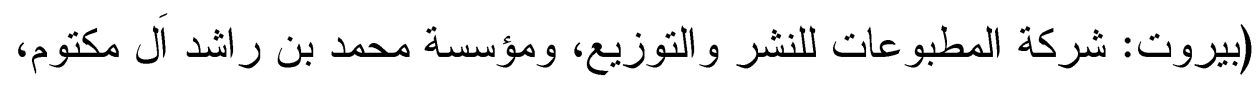

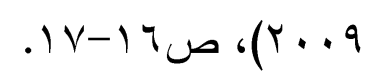

r. هز اع احمد سالم المنصوري، السياسة الخارجية في دولة الامارات العربية

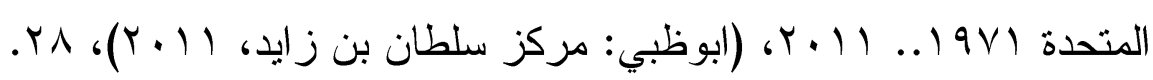

Alexis Normand, Les Emirats Du Golf,Au Defi بركز

Delurerture,(Paris; harm\& Then, 2011), pp.43-44;

الداود واَخرون، التجارب الوحدوية العربية المعاصرة: تجربة دولة الامارات

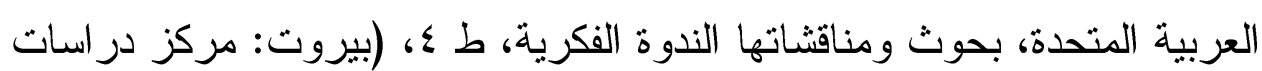

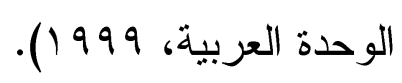

ع. عبد الخالق عبدالله، زايد الأب المؤسس، في: كتاب في حب زايد، طا، (الثارقة:

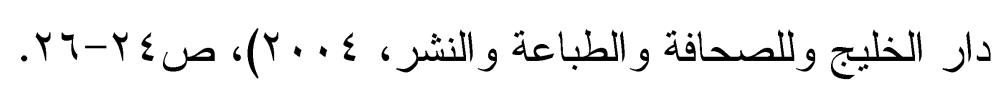

0. ج.ج. لوريمر، وليل الخليج: القسم التاريخي، ترجمة مكتب الترجمة بديوان حاكم

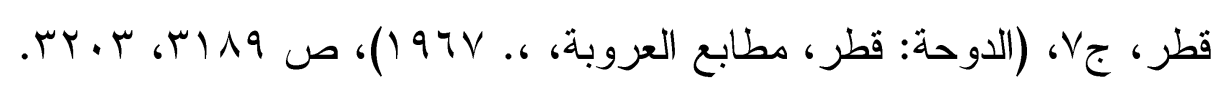

See: Mohamed G. AL- Rumaihi, Factors of Social and

Economic: Development in the Gulf in the Eighties, in: klaus

Jurgen GantzeL and Helmut Mejcher, (eds) Oil, the Middle

East, North Africa and the Industrial States: Developmental and International Dimensions, International Gegen- wark,

Bd,padreborn: f. Schningh, 1984), pp.208-210.

OPEC Statistical Bulletin (1971) and Neue Zeit, No.15 (1981) .

V . اسامة عبد الرحمن، البيروقر اطية النفطية ومعضلة التنمية: مدخل الى دراسة

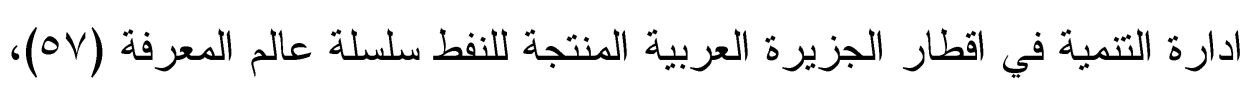

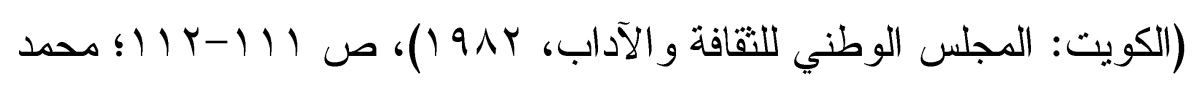


رشيد الفيل، التكامل الاجتماعي و السياسة السكانية الموحدة الدول الخليج العربي،

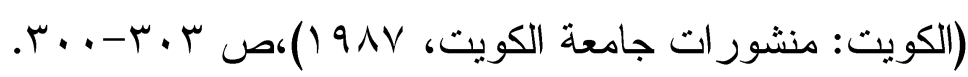

A. وليد محمد مصطفى، التطور الاقتصادي و الاجتماعي للإمار ات العربية المتحدة 19V1 - (991 (كتاب الخليج (الشارقة: مركز الخليج للار اسات و الصحافة

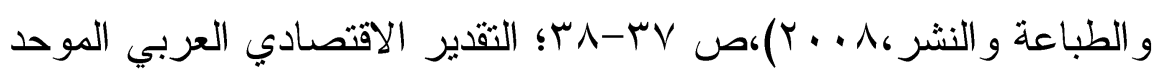

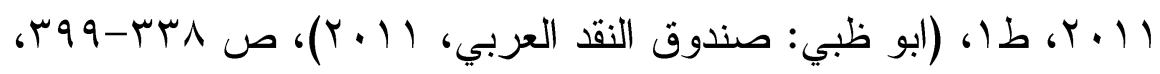

Normand, Op. Cit., pp.49-57-64.

9. محمد بن راشد آل مكتوم، رؤيتي التحديات في سباق التميز، طب، (دبي: موتيفيت

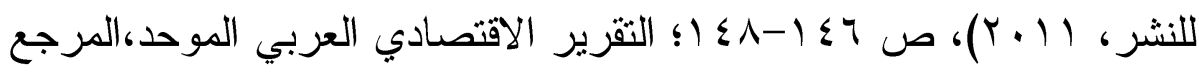

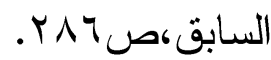

•

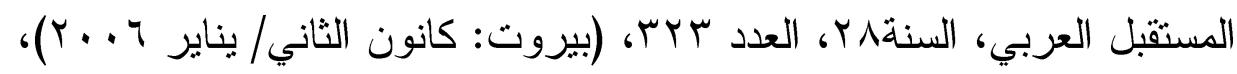

Christopher Davidson, Diversifnication in $\mathrm{Abu} 60 \wedge-0 \mathrm{~V}$ Dhabi and Dubi: The Impact On National Identity and the Ruling Bargain, in: popular Culture and Political Iditity in the Arab Gulf States, (ed), Al-anoud Al- sherekh \&Robert Springborg, (London: Middle East in Intituteat SoAS, 2008),pp. 143-152.

ا1 . عبد الملك خلف التميمي "الخليج العربي: دراسة في التاريخ الاقتصادي و الاجتماعي" مجلة العلوم الاجتماعية العدد ب، (الكويت: حزيران- يونيو (919))، ص V إ محمد عباس ابر اهيم، "الابعاد الاجتماعية الثقافية و الحضرية في مجتمعات الخليج العربي"، مجلة شؤون اجتماعية، العدد آب،

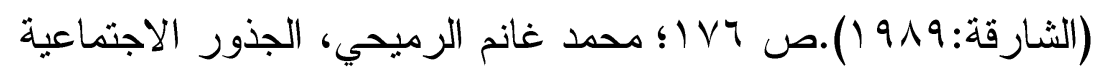
للايمقر اطية في مجتمعات الخليج العربي المعاصرة، طب، (الكويت: شركة كاظمة للنشر و الترجمة و التوزيع، ع^ه (1)، صه9. 


\section{r ا. منى محمد الحمادي،بريطانيا والاوضاع الادارية في الامار ات المتصالحة

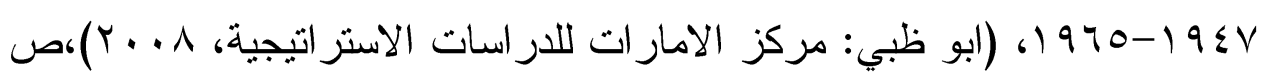
$.18-19$

Jill Grystall,DiL and Politics in the Gulf: Rules and Merchants in Kuwait and Qatar, Cambridge Middle East Library, (Cambridge (UK): New York: Cambridge University Press, 1990),pp.24-48, Michael Field, the merchants: the Big Business Families of Saudi Arabia and the Gulf States, (Woodstock Ny:

Overbook press, 1985).

ع ا. أسحق يعقوب القطب و عبدالاله أبو عياش، النمو و التخطيط الحضري في دول الخليج العربي (الكويت: وكالة المطبوعات، • م191)، صسس،. . Normand, op. cit,pp.71-72 1. . جامعة الدول العربية، الامانة العامة وآخرون، التقرير الاقتصادي العربي الموحد Y . . Y، (القاهرة: جامعة الدول العربية، الامانة العامة، ابو ظبي: صندوق النقد

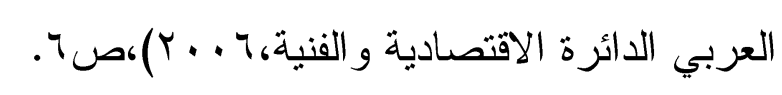
7 ا. عاطف وصفي،" متغيرات و عمليات الامتز اج الثقافي في دولة الخليج العربي"،

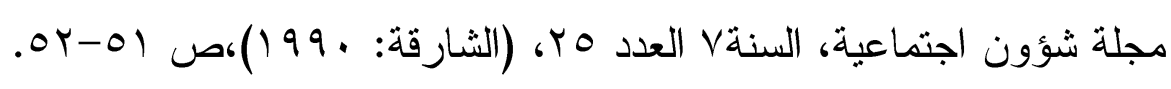
Levon H .Milikian," Gulf Reaction to Western Culture presswes . IV

Pape presented at: the Arab Gulf and the west (Conference), (ed) by B.R. Pridham, (London: University of Exeter, Center for Arab Gulf Studies, 1985),pp.204-205. 11. عزة علي عزت، الصحافة في دول الخليج العربي، الكويت، البحرين، الامار ات العربية، قطر، عمان، مراجعة سنان سعيد، (بغداد: مركز التوثيق الاعلامي الدول

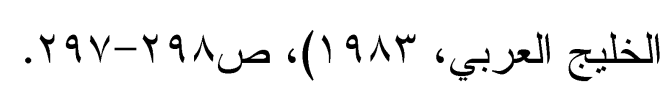

9 1. محمد جابر الانصاري "كيف تلائم بين عالم النفط وقيم الثقافة "، مجلة الدوحة،

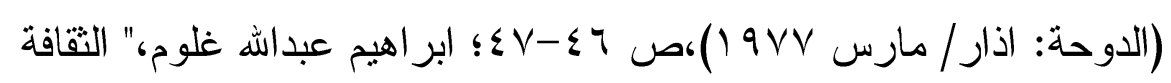

بوصفها خطاباً ديمقر اطية: نموذج الثقافة في مجتمعات الخليج العربي"، مجلة 
المستقبل العربي، السنةء (، العدد 04 1، (بيروت: شباط/ فبر اير ب99 ())، ص

$$
.01-0
$$

•r. . راشد علي سعيد بن علوان، الاوضاع الاقتصادية و الاجتماعية في الامار ات

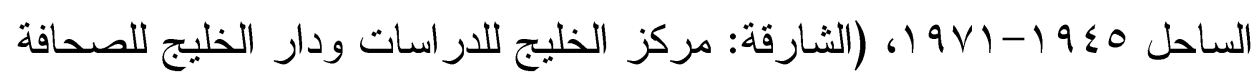

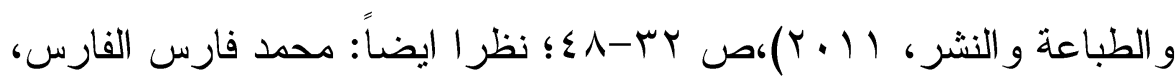
الاوضاع الاقتصادية في الامارات الساحل (دولة الامار ات العربية المتحدة حالياً)

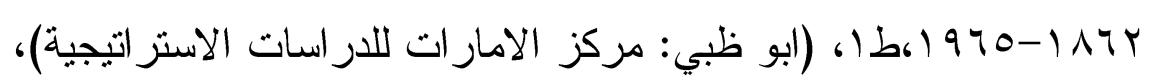

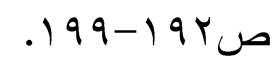
اr. عبد القادر زلوم، عمان و الامار ات السبع، در اسة جغر افية وانسانية، (بيروت: دار

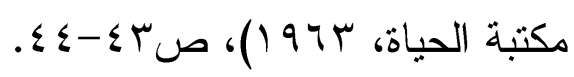

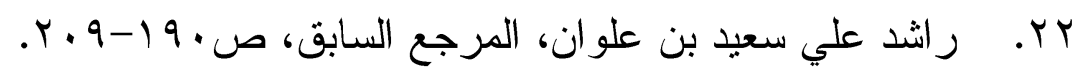

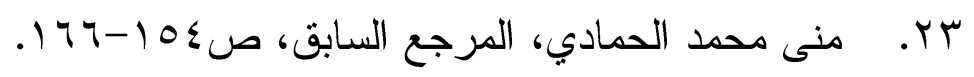

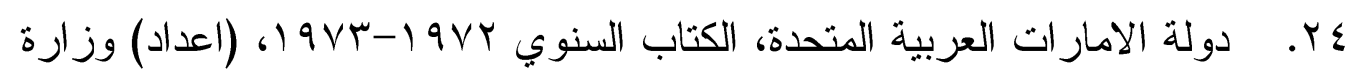

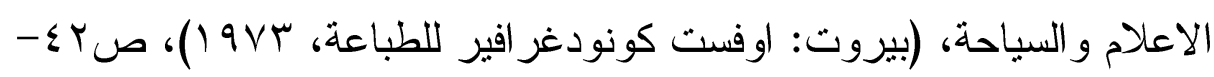
ז

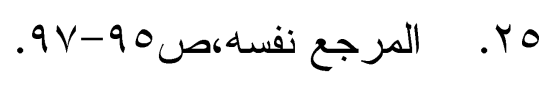

بr. فراوكه هيرد - باي، من الامارات المنصالحة الى دولة الامارات العربية

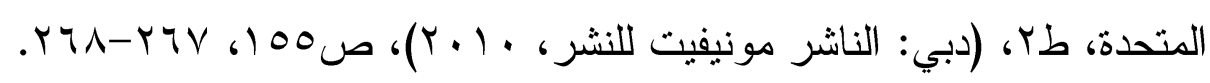

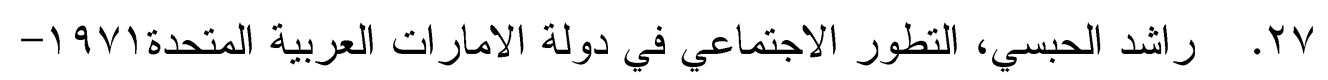

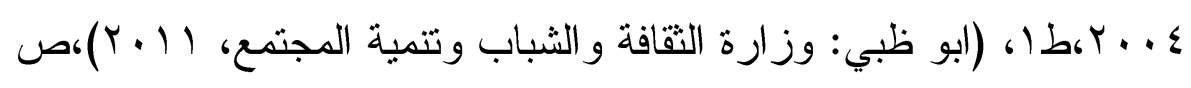
$.9 \varepsilon-94$

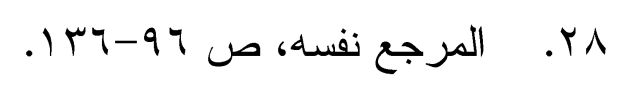

وץ. راينركودرس وفريدشولتز، البدو، الثروة و التغيير : در اسة في التنمية الريفية للإمار ات العربية المتحدة وسلطنة عمان، ترجمة عبدالاله أبو عياش، السلسلة 
الجغر افية،(الكويت: اصدار ات جامعة الكويت، سر9 ())، صه • 1-7 • (؛ امل يوسف الصباح، سكان دولة الامار ات العربية المتحدة: دراسة في جغر افية

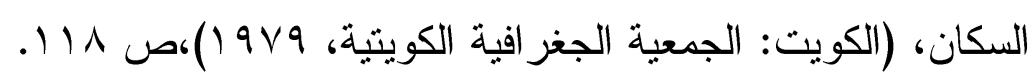
•". عبد العزيز البسام،" السياسة التربوية في دولة الامار ات: و اقعها و اتجاهات تطويرها"، في: محمود علي الداود وأخرون، المرجع السابق، ص 0 ـه.

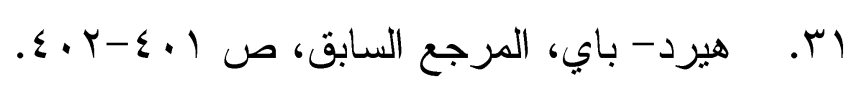

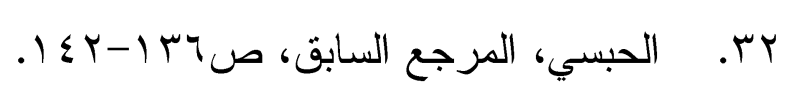

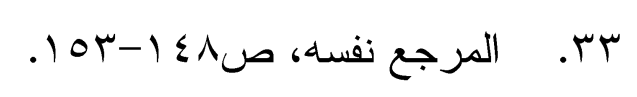

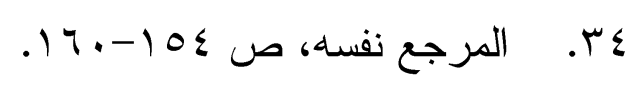

هم. مريم سلطان يوتاه،" تقييم السياسة التعليمية في دولة الامار ات "،في: و اقع التعليم و الأفاق المستقبلية لتطويره في دولة الامار ات العربية المتحدة، طا، (ابو ظبي:

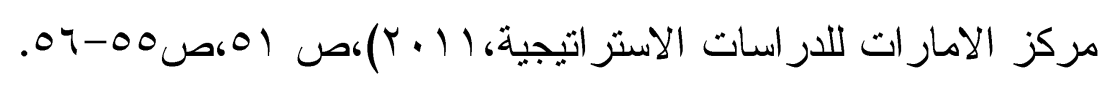
بس. ميك راندل،" الاتجاهات العالمية وتأثير ها في التعليم العالي في دولة الامار ات العربية المتحدة،" في: و اقع التعليم و الافاق المستقبلية لتطويره في دولة الامار ات العربية المتحدة، ص V Vr. انظر : محمد جابر الانصاري، لمحات من الخليج العربي: دراسات في تاريخ وثقافة ورجاله وفلكلوره الشعبي، (بيروت: الشركة العربية للوكالات و التوزيع،

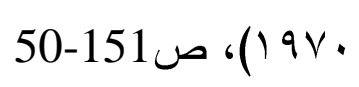

باقر النجار،" المجتمع المدني في الخليج و الجزيرة العربية،" ورقة قدمت الى: المجتمع المدني في الوطن العربي ودوره في تحقيق الديمقر اطية، بحوث ومناقشات الندوة الفكرية التي نظمها مركز در اسات الوحدة الوطنية، (بيروت: المركز، ب99 ())،

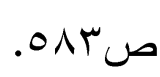

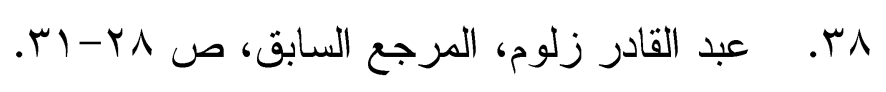


وس. انظر: الكتاب السنوي الدولة الامارات العربية المتحدة r ...r، (ابو ظبي: وزارة

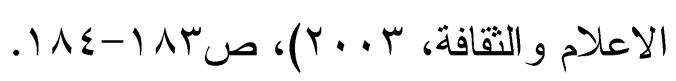

• ع. عبد الخالق عبدالله، الحركة الثقافية في الامار ات، (ابو ظبي: المجمع

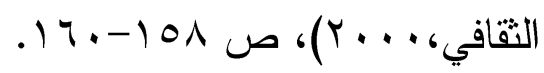

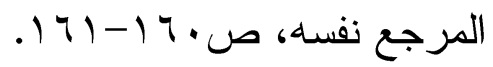

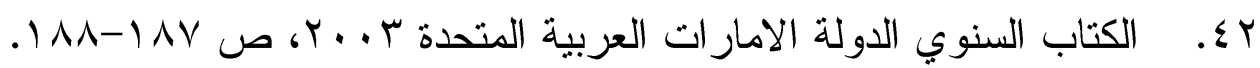

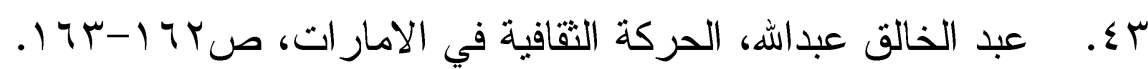
ع ـ. انظر : الدليل التعريفي، جائزة الشيخ زايد للكتاب، (ابوظبي: هيئة ابو ظبي

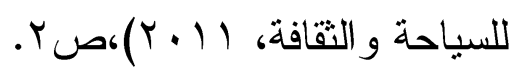

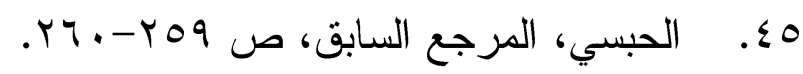

جـ. عبد الخالق عبداله، الحركة الثقافية في الامارات، ص بح ا-سج ا.

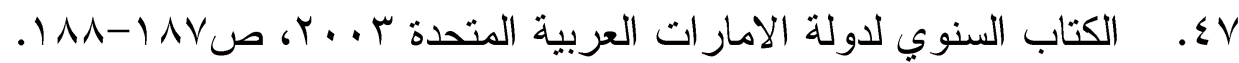

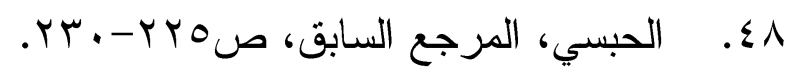

9ـ. دولة الامار ات العربية المتحدة الكتاب السنوي 991 1، (لندن: شركة تر ايدنت

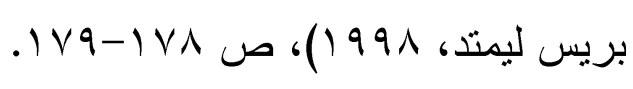

•0. بلال بدور،" المشهر الثقافي في دولة الامار ات،" صحيفة جب سبتمبر، في الموقع

الالكتروني، .www.26SeplnNews weak article. Ph plng= Arabic WWW. انظر : "الموسوعة الالكترونية لدولة الامار ات،" في الموقع الالكتروني، ؛دولة الامار ات العربية المتحدة الكتاب السنوي Uaepedia.ae/index.php;

$$
.1 V \varepsilon-1 V \cdot 0 \text { ( } 1991
$$

ro. "الموسوعة الالكترونية لدولة الامار ات،" المرجع السابق؛ دولة الامار ات العربية

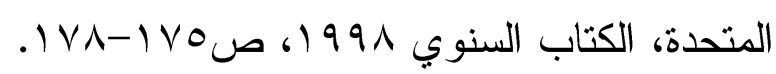

Nada Moutada-Sebbah Mohammed aL- Mutawa,John w. Fox .or and Tim Wahers",Media as Social Matrix in the United Arab Emirates," in: Popular Culture,pp.121-133. 
00. دولة الامار ات العربية المتحدة الكتاب السنوي1991، ص.111-182. ل

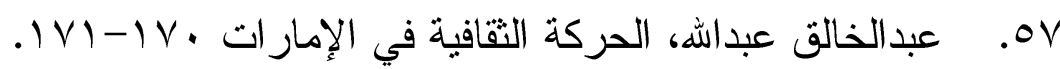

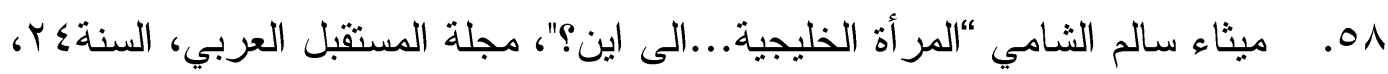

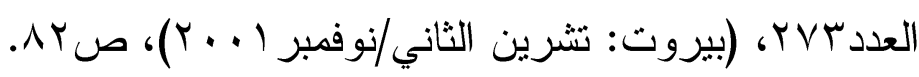
ه9. انظر : جمعية نهضة المر أة الظبيانية في دولة الامار ات العربية المتحدة،

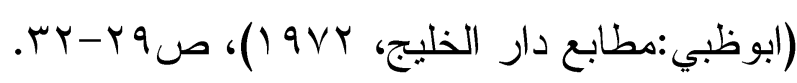

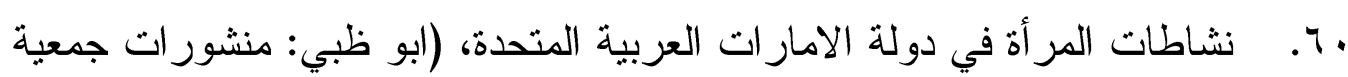

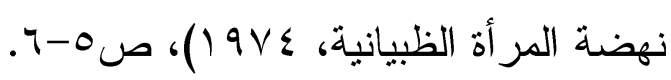
آجا. انظر : عن جمعية المرشدات في الامارات الموقع الالكتروني

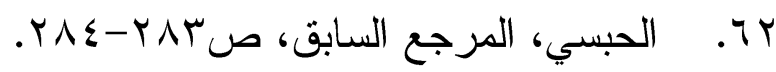

$$
\begin{aligned}
& \text { rצ. }
\end{aligned}
$$

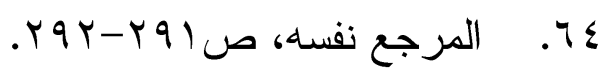

ه7. دولة الامار ات العربية الدتحدة، الاتحاد النسائي العام الاستر اتيجية الوطنية لتقدم المرأة في دولة الامار ات العربية المتحدة، (ابوظبي:الاتحاد النسائي العام،

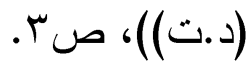

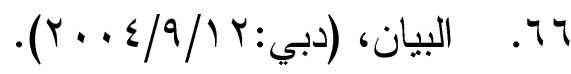

TV. . عبدالهادي خلف “دور المرأة في الاندماج الوطني في دولة الامارات"، في:

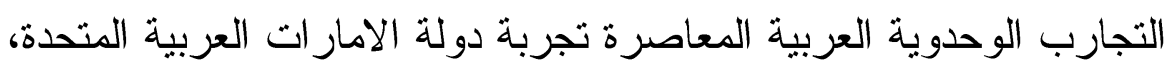

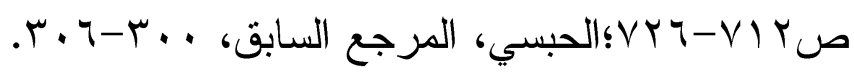




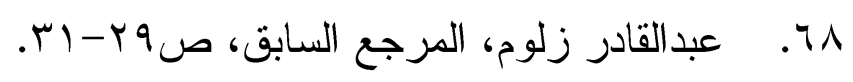

79. نجيب عبداله الشامسي، الالعاب و الالغاز الثعبية في دولة الامارات ، طا،

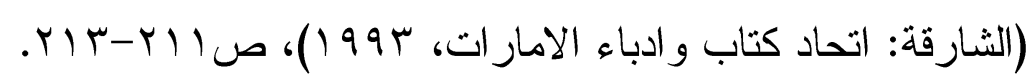

(انظر : الصقارة تزراث انساني حي"، (ابوظبي: هيئة ابو ظبي للسياحة و الثقافة،

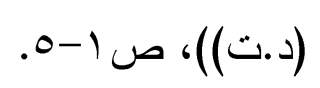

ال V "التغرودة الثعر البدوي التقليدي المغنى"، (ابوظبي: هيئة ابو ظبي للسياحة و الثقافة،

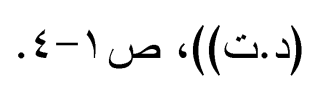

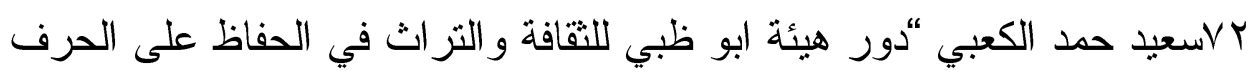
و الصناعات اليدوية “، في: التراث غير المادي وكيفية الحفاظ عليه واعداد قو ائم

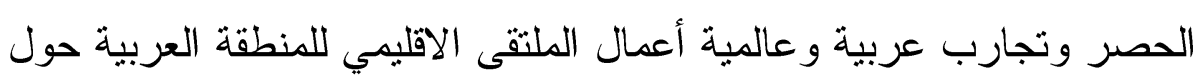
صون التزاث غير المادي و اعداد قو ائم الحصر، (تحرير و اشر اف) ناصر علي

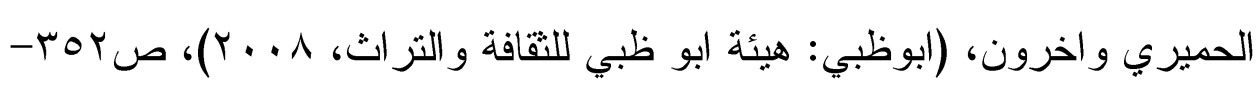

. צ.

r Vاطف صدقي “تحليل وظيفي للحكايات الشعبية في مجتمع الامار ات"، في: أبحاث الحلقة الر ابعة للمر اكز والهيئات المهتمة بدر اسات الخليج العربي و الجزيرة العربية في ابوظبي في نوفمبر ع 9 1، (ابوظبي: مركز الوثائق و الدراسات،

$$
\text { (19人r }
$$

(74)Fred Hewson and Hasan M. Naboodah,"Heritage and . . CulturalNationalism in the United Arab Emirates", in: Popular Culture and Political,pp.15-28. o.vبد العزيز المسلم “تجربة دولة الامارات في حفظ التراث الثقافي غير المادي “، في:

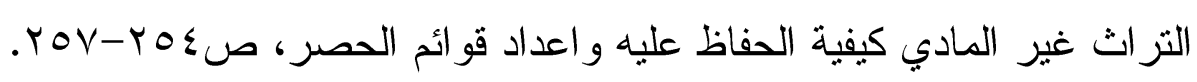

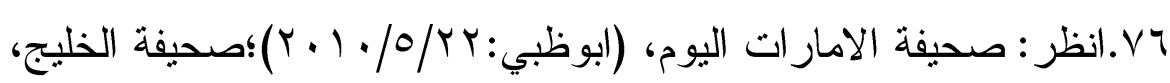

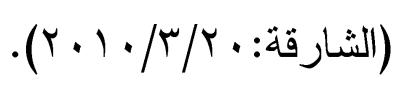




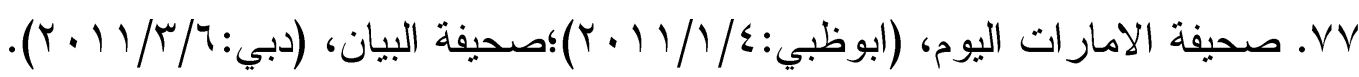

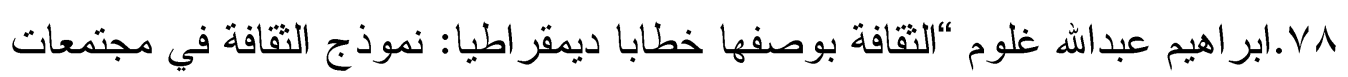

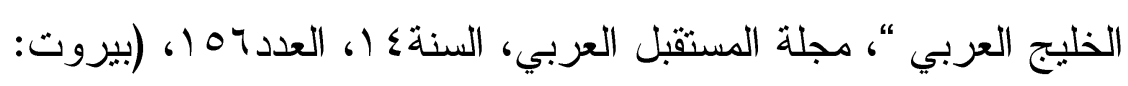

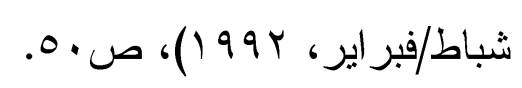

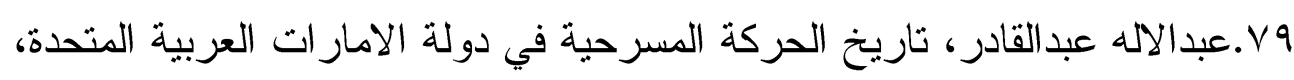

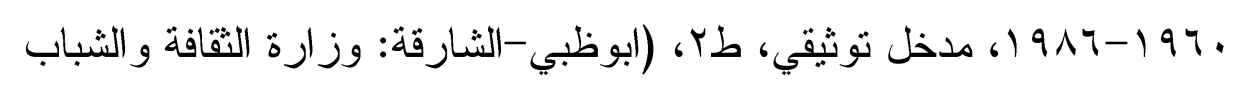

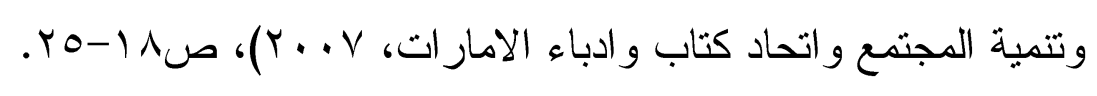

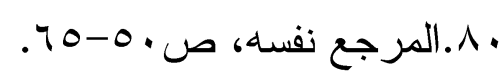

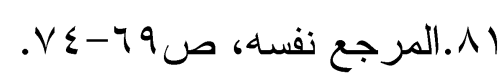

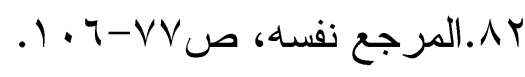

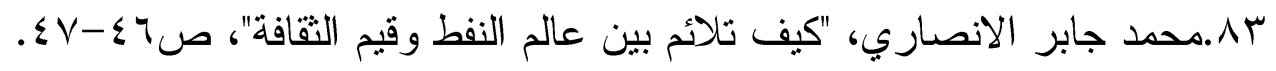

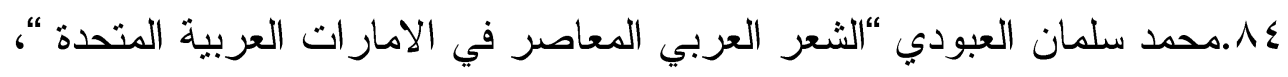

$$
\text { موسو عة معجم البابطين، في الموقع الالكتروني: }
$$

Emirate/studies/encyclopedia/ prize.orgwww.albabtain .V هـ.عادل خزام “تطور الحركة الشعرية في الامارات خلا القرن العشرين “، صحيفة

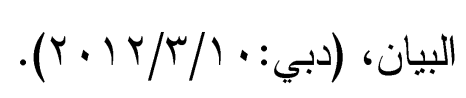
4.人.انظر : "الحركة الشعرية في الامار ات"، في الموقع الالكتروني

t19Lhtm/Ub/www.Uae7.com NV

11.بدر عبدالمالك، القصة القصيرة في الصوت النسائي في دولة الامار ات العربية.

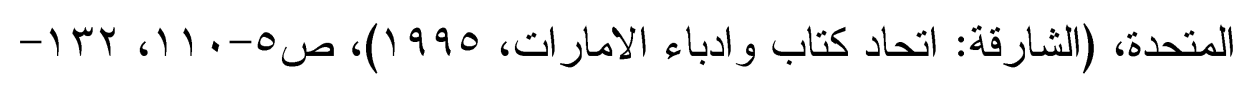
ros 


\section{9 ^.انظر موسوعة ويكيبيديا الامارات في الموقع الاكتروني :}

.Emirate/wiki/www.ar.wikipedia.org

The Cultural History of UAE1971-2004

Dr.mufeed G.al-zaidy

Center for Strategic \&International Studies

University of Baghdad

This article is a study of Culture and its impact in the Society. It is Important to Understand the Structure of Social powers and people and Economic Structure. This Research Consist of three Chapters, the First about Economic Situation in the Emirates of the Coast Oman, and Second Chapter deals with Social Structure, and third Chapter concerns with the Culture, police,education,cultural Communities, media and press, the woman Culture work, Population culture,arts, and cultural movements. 